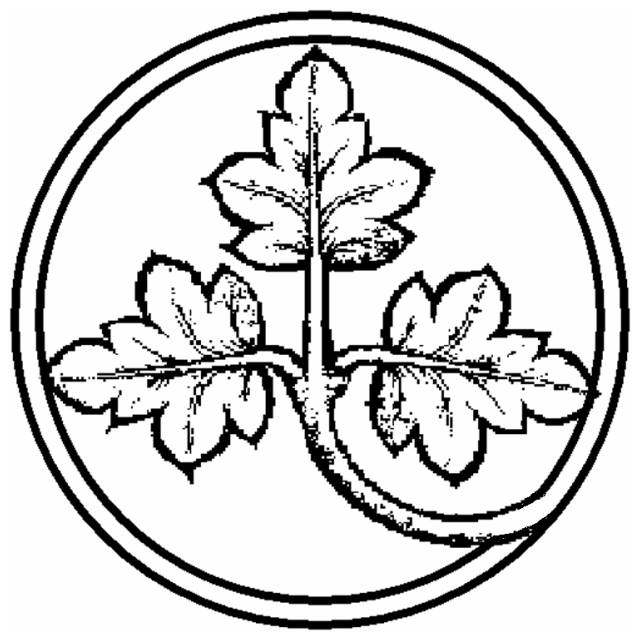

\author{
Preprints of the \\ Max Planck Institute \\ for Research on Collective Goods \\ Bonn \\ 2005/16
}

Making International Human Rights Protection More Effective: A Rational-Choice Approach to the Effectiveness of Ius Standi Provisions

Anne van Aaken 


\section{Making International Human Rights Protection More Effective: A Rational-Choice Approach to the Effectiveness of lus Standi Provisions}

Anne van Aaken

September 2005 


\title{
Making International Human Rights Protection More Effective: A Rational-Choice Approach to the Effectiveness of lus Standi Provisions
}

\author{
Anne van Aaken ${ }^{1}$
}

Empirical research shows that international human rights law is to a large extent ineffective. Individual complaint mechanisms are the only significantly effective enforcement mechanism. Certainly many variables influence the success of enforcement through judicial or quasi-judicial mechanisms but one important variable are provisions of ius standi as they have a gate-keeping function. International human rights law can be rendered more effective if individual victims have both de jure and de facto access to its remedies. This article analyzes the different incentives provided by complaint mechanisms for individuals, groups or NGOs to make use of international human rights bodies. They are such, that an insufficient enforcement of IHRL can be expected.

1 Dr. iur. lic.rer.pol. Anne van Aaken, Senior Research Fellow, Max Planck Institute for the Research on Collective Goods, Kurt-Schumacher-Strasse 10, 53113 Bonn, Germany, Email: vanaaken@coll.mpg.de.

I would like to thank the participants of the International Human Rights discussion group at the Max-PlanckInstitute for helpful hints and discussions. Many thanks also go to the participants of the conference “Analyzing International Conflict Resolution”, Saarbrücken, Germany, 15th - 17th Oct. 2004, especially Stefan Oeter for his comment as well as Gralf-Peter Calliess, Tom Ginsburg, Larry Helfer, Wilfried Hinsch, Roland Kirstein, Karl Meessen, Eric Neumayer and Eric Posner. Special thanks go to Stefan Bechthold, Rudolf Bernhardt, Pia Carazo, Christoph Engel, Matthias Goldmann, Martin Hellwig and Stefan Voigt for very helpful critique. Last but not least, I would like to thank Sara von Skerst for help with the footnotes. All remaining errors are of course mine. 


\section{Introduction}

Unfortunately, we do not live in the best of all human rights worlds. This raises the question of potential causes of the current situation and how it can be improved. The article deals with ius standi provisions in international human rights law (hereinafter IHRL), argues that they are not effectively designed from an individual complainants' point of view and proposes a broadening of ius standi provisions as one potential means of improvement.

Questions pertaining to human rights first arise at the domestic level between the state and the individuals under its jurisdiction. States are the main addressees of human rights obligations. ${ }^{2}$ Where national protection fails, individuals may bring their complaints before international bodies. A growing number of international bodies with jurisdiction to protect individuals against human rights violations committed by states within their own jurisdiction have been created. ${ }^{3}$ It is sometimes claimed that we are living through a "human rights revolution in progress", 4 in which (i) the recognition of the objective character of obligations to protect human rights, ${ }^{5}$ (ii) the acceptance of a collective guarantee of compliance with these obligations and last but not least (iii) the right of individual complaints are all crucial parts. Nevertheless, it is also true that the institutions for the enforcement of human rights are still rather weak. Empirical research ${ }^{6}$

2 Nearly all countries, especially in Eastern Europe have incorporated IHRL in their legal orders. The European Convention, for example, is law of the land in most European countries. Thus, they may also be enforced by national courts and become effective in that way. For a short overview on the interplay between IHRL and national law, see Ralph Steinhardt, "The Role of Domestic Courts in Enforcing International Human Rights Law”, in: Hurst Hannum (ed.), Guide to International Human Rights Practice, 2004, Ardsley, NY, 267-289.

3 Courts, commissions and committees are all dealt with together as they all allow for individual complaint mechanisms. Commissions and committees are not judicial bodies in the proper sense as they issue only nonbinding decisions. In the text, the term "judicial body" is used to include all of them. Furthermore, compliance with decisions does not necessarily depend on their binding nature.

$4 \quad$ Thomas Buergenthal et al., International Human Rights in a Nutshell, 2002, St. Paul, at 24.

5 Human rights treaties are distinct from other treaties, which are characterized by mutual and reciprocal concessions and obligations, in that human rights treaties find inspiration in considerations of a superior order, the ordre public. In creating obligations for states vis-à-vis human beings under their jurisdiction, the norms of these treaties not only require States Parties to take joint action for human rights protection (i.e., through the exercise of a collective guarantee), but also, and above all, oblige each State Party to provide an internal legal order to enforce these rights, in relations between the public power and the individual. See instead of many Hermann Mosler, "The Protection of Human Rights by International Legal Procedure", Georgetown Law Journal 52 (1964), 800-823, at 818 et seq. considering the function of the European Commission. The European Court of Human Rights (ECtHR) and the Inter-American Commission (IACHR) understand the respective human rights treaties not only as a reciprocal treaty between states but as an objective order. The ECtHR stated in Ireland v. The United Kingdom (Appl. No. 5310/71), 25 Eur.Ct. H.R (ser. A) (1978), Judgment of 18 January 1978, at para. 239 that: "...unlike international treaties of the classic kind, the Convention comprises more than merely reciprocal engagements between Contracting States. It creates, over and above a network of mutual, bilateral relationships, objective obligations, which, in the words of the Preamble, benefit from a "collective enforcement". Likewise the I/A Court H.R., The Effect of Reservations on the Entry into Force of the American Convention on Human Rights. Advisory Opinion OC2/82 of September 24, 1982, at para. 29. More generally for different types of treaties, see Gerald Fitzmaurice, "Second Report on the Law of Treaties", UN doc. A/CN.4/107, Yearbook of the International Law Commission, Vol. II , 16-70 (1957), at 54 et seq. called those obligations "integral". See for this distinction also Joost Pauwelyn, "A Typology of Multilateral Treaty Obligations", European Journal of International Law 14 (2003), 907-951, at 933 especially for IHR Treaties.

6 Oana A. Hathaway, “Do Human Rights Treaties Make a Difference?”, Yale Law Journal 111 (2002), 19352042. In substance not different, see Eric Neumayer, Do International Human Rights Treaties Improve Respect for Human Rights?, Journal of Conflict Resolution 50 (2006), forthcoming. His findings suggest that 
shows that IHRL is largely ineffective. ${ }^{7}$ Why is that so? International bodies carry out their task of human rights enforcement and compliance monitoring mainly based on self-reporting by states or on inter-state complaints. The reporting system is considered the backbone of monitoring compliance. Still, those procedures may be deemed insufficient for ensuring compliance. Inter-state complaints have been thoroughly and predictably underused. ${ }^{8}$ In contrast, individual complaint mechanisms are the only enforcement mechanism having at least a weak empirical

rarely does treaty ratification have unconditional effects on human rights. Instead, improvement in human rights is typically more likely the more democratic the country or the more international non-governmental organizations its citizens participate in. Conversely, in very autocratic regimes with weak civil society, ratification can be expected to have no effect and is sometimes even associated with more rights violation. He also summarizes the findings of less comprehensive empirical studies which all find more or less the same result.

7 Effectiveness and compliance are different but related notions. Determining whether a state complies with a treaty requires comparing the relevant state activity with the treaty's requirements. Effectiveness is directly related to, but distinct from, compliance and regards causality. A state may comply with a treaty, that is, its actions comport with the requirements of the treaty, but the treaty may nonetheless be ineffective in changing that state's practices. For these notions see Andrew T. Guzman, "A Compliance-Based Theory of International Law”, California Law Review 90 (2002), 1823-1887, for compliance theories Harold Hongju Koh, “Why do Nations Obey International Law?”, Yale Law Journal 106 (1997), 2599-2659 and Laurence R. Helfer/Anne-Marie Slaughter, “Toward a Theory of Effective Supranational Adjudication”, Yale Law Journal 107 (1997), 273-391.

Abstracting from statistical notions of effectiveness and adopting a broader notion, one may argue that IHRL may build up a mentality conducive to human rights in responsible organs of the state and it may influence national and international legitimacy of a government. It may also signal reliance, see David H. Moore, “A Signalling Theory of Human Rights Compliance”, Northwestern University Law Review 97 (2003), 879-910, at 905. Court decisions may also improve public deliberation and pressure on the state and therefore change the discourse, see Thomas Risse, "International Norms and Domestic Change: Arguing and Communicative Behavior in the Human Rights Area”, Politics and Society 27 (1999), 529-559, who advocates a "spiral theory" of norm socialization, which applies also in the field of IHRL. Thus, the approach taken in this paper does not contradict the "spiral theory" or other theories but rather adds one component.

8 Dinah Shelton, “The Participation of Nongovernmental Organizations in International Judicial Proceedings”, American Journal of International Law 88 (1994), 611-642, at 613 and 615; Anne F. Bayefsky, The UN Human Rights Treaty System, 2001, The Hague, at xv and Laurence Helfer/Anne-Marie Slaughter, supra note 7, at 298 et seq. Inter-state complaints are possible under the following agreements: Art. 24 of the European Convention on Human Rights and Fundamental Freedoms (ECHR); Art. 45 of the American Convention on Human Rights (ACHR); Art. 49 of the African Charter on Human and Peoples' Rights (African Charter); Art. 41 of the International Convenant on Civil and Political Rights (CCPR); Art. 11 of the Convention on the Elimination of Racial Discrimination (CERD); and Art. 22 of the Convention Against Torture and Other Cruel, Inhuman or Degrading Treatment or Punishment (CAT). Consequently, a State can lodge an application with a treaty-body when it has reason to believe that another State has violated a right guaranteed in one of these conventions. Up to 2001, the inter-state complaint procedures of the CCPR, the CERD and the ACHR have never been used, and the CAT has been used twice, however. Under the ECHR there have been 21 applications by states in 13 cases relating to no more than seven situations, see Søren C. Prebensen, "Inter-State Complaints Under Treaty Provisions - The Experience Under the European Convention on Human Rights”, in: Gudmundur Alfredsson et al. (eds.), International Human Rights Monitoring Mechanisms. Essays in Honour of Jakob Th. Möller, 2001, The Hague, 533-559, at 543. As Pieter van Dijk/Godefridus J. van Hoof, Theory and Practice of the European Convention on Human Rights, 1998, The Hague, at 43 point out: [I]t is evident that the right of complaint of States has proved not to be very effective.... [T] ]he contracting States have not been willing to lodge complaints about situations in other States where no special interest of their own was involved. Such a step generally even runs counter to their interest in that a charge of violation of the Convention is bound to be considered an unfriendly act by the other party, with all the political consequences that may be involved.” Suggestions for strengthening the inter-state complaint mechanisms are given by Scott Leckie, "The Inter-State Complaint Procedure in International Human Rights Law: Hopeful Prospects or Wishful Thinking?”, Human Rights Quarterly 10 (1988), 249-303. 
significance of effectiveness. Ratification of e.g. the First Optional Protocol to the International International Convenant on Civil and Political Rights is associated with less rights violations. ${ }^{9}$

It is submitted that we should not simply accept the empirical finding that IHRL is largely ineffective on the whole, yet more effective if there is the possibility of individual complaint mechanisms. It seems insufficient for international human rights lawyers to stop short with the analysis at that point. Rather we need to ask how those mechanisms can be rendered more effective. Considering the number of individuals covered by the respective IHR treaties ${ }^{10}$ and reports about ongoing human rights abuses, it seems appropriate to hypothesize that many meritorious human rights complaints are not brought before international judicial bodies. In short: IHRL individual complaint mechanisms are underused too. In order to answer the question why that is so, a social science analysis which is able to uncover the underlying incentive structure for potential complainants is needed. Rights are largely illusory without the de iure and de facto capability and incentive to enforce them, that is, IHRL can only be effective if individual victims have both de jure and de facto access to its remedies.

Assuming that effectiveness of human rights treaties is desirable, ${ }^{11}$ and hypothesizing that individual complaint mechanisms foster effectiveness, one needs to ask how the existing complaint mechanisms can be rendered more effective on an international plane. ${ }^{12}$ Judicial or quasi-judicial bodies can, of course, only act if there is a complainant. Admissibility conditions for complaints to international bodies have a gate-keeping function in view of which cases are dealt with on their merits. One of the most important of these admissibility conditions - and one which is legally changeable - is the ius standi. ${ }^{13}$ Ius Standi under a complaints procedure determines who may submit a complaint under one of the instruments under review. If a complainant does not have standing under the instrument, the complaint will be rejected by the judicial body on formal grounds, without consideration of the merits. A central issue of the standing doctrine is the nature of the injury alleged, i.e. the substantive right. In most human rights treaty regimes, establishing ius standi requires both an assertion that one has suffered a distinct and palpable injury, and that there is a fairly traceable causal connection between the claimed injury and the challenged conduct.

9 Hathaway, supra note 6, at 1999. Eric Neumayer, supra note 6, finds the same result for the Optional Protocol of the CCPR. Succumbing to individual complaint mechanisms might also have a positive signaling effect to other states. Antônio Augusto Cançado Trindade, “The Consolidation of the Procedural Capacity of Individuals in the Evolution of the International Protection of Human Rights: Present State and Perspectives at the Turn of the Century”, Columbia Human Rights Law Review 30 (1998), 1-27 also stresses the importance of the individual complaint mechanisms for recognizing that human rights are no longer simply "granted" by the state.

10 Approximately 1.4. billion people are covered the UN-treaty based instruments, see Jack Goldsmith/Eric Posner, The Limits of International Law, 2005, at 120.

11 The question if states really want IHRL to be more effective is left unanswered here.

12 For an overview on theories dealing with enforcement on the national level, see Harold Hongju Koh, "How is International Human Rights Law Enforced?”, Indiana Law Journal 74 (1997), 1397-1417.

13 For the concept of standing and different terminology concerning the concept, see Franz Matscher, Standing Before International Courts and Tribunals, in: R. Bernhardt (ed.), Encyclopedia of Public International Law, Vol. IV (2000), 594-600. 
If an individual having ius standi takes a case to an international body which confirms the alleged human rights abuse, the individual gets private relief in the case at hand which is a private good. Yet, at the same time, the individual provides a collective good by setting a legal precedent and/or by providing the factual basis in court for individuals similarly situated. This point is even more valid for substantive rights, which entail a collective good aspect per se (e.g. minority rights or large-scale violations).

A short comment on the theory of collective goods and the incentives created by a collective good problem is apposite here. In economics, a collective (or public) good is a good that is hard or even impossible to produce for private profit, because the market fails to account for its large beneficial externalities. ${ }^{14}$ By definition, collective goods possess two properties. They are (1) non-rivalrous - its benefits fail to exhibit consumption scarcity; once it has been produced, everyone can benefit from it without diminishing other's enjoyment and (2) non-excludable once it has been created, it is very difficult or impossible to prevent access to the good. Examples are a street signs, clean air or the rule of law. A pure collective good is an extreme case though; many goods encompass private and public aspects. ${ }^{15}$ In IHRL, a complaint is usually a mixed good. This poses immediately the question of who, then, provides public goods. Once they exist, they are there for all to enjoy. So it is often the most rational strategy for private actors to let others go first and seek to enjoy the good without contributing to its production. This is a dilemma that public goods face. Without some sort of collective-action mechanism, they risk being underprovided due to the free-rider incentive as individuals usually take into account the private benefit, but not the public benefit when acting. If all individuals (victims) would have perfect information, then a collective good problem can be solved through pure coordination. ${ }^{16}$ E.g., if several victims are affected and if this group of victims could be organized, the collective action problem could be mitigated. But once there is asymmetric information and participation in the collective good is voluntary, the problem is not perfectly solvable. ${ }^{17}$

Taking a case to court amounts to a voluntary contribution to the provision of a collective good as potential gains (from winning) cannot be completely internalized whereas potential losses (from losing) are completely internalized. From a rational-choice perspective, there are few incentives for an individual to provide a collective good. If one focuses on the possibility of judicial enforcement as a means of fostering compliance, it can be diagnosed that substantive rights and procedural rights are not effectively aligned in most human rights treaties.

14 An externality occurs in economics when a decision (for example, to pollute the atmosphere) causes costs or benefits to individuals or groups other than the person making the decision. In other words, the decisionmaker does not bear all of the costs or reap all of the gains from his action. Also human rights violations may be viewed as externalities.

15 For a general treatment public goods see Richard Cornes/Todd Sandler, The Theory of Externalities, Public Goods, and Club Goods, 1986. A club good allows exclusion for those not in the "club"; see for the club good notion James M. Buchanan, “An Economic Theory of Clubs”, Economica, 32 (1965), 1-14. Mark Bagnoli/Barton L. Lipman, "Private Provision of Public Goods Can Be Efficient”, Public Choice 74 (1992), 59-78.

17 See Martin Hellwig, Public-Good Provision with Many Participants, Review of Economic Studies 70 (2003), 589-614. 
This article seeks to analyze the different incentives provided by individual complaint mechanisms for individuals, groups or non-governmental organizations (hereinafter NGO) to make use of international human rights bodies. More specifically, the effectiveness of human rights treaties by means of individual complaint mechanisms will be analyzed, using a rational-choice looking glass for incentives of individuals to bring complaints depending on the one hand on the right in question and depending on the provisions of ius standi on the other hand. The rational-choice approach as a social science approach allows us to address the "why-question" on the individual level. As of yet, nothing can be found in international law and international relations literature concerning that question. ${ }^{18}$

From a rational-choice perspective, under what circumstances can individuals be expected to make use of complaint mechanisms under human rights treaties? Do complaints by NGOs, class action and actio popularis (hereafter referred to as "collective complaints") make sense from a rational-choice perspective? What kinds of incentives are generated for the individual by such complaint mechanisms? How should it be evaluated from a normative standpoint that legal mechanisms are de lege lata such as to deter human rights suits? If higher effectiveness of human rights treaties is desirable, what kind of legal mechanisms should be suggested?

As a means of addressing such questions, this article first describes the problem theoretically, by clarifying the relevant concepts of rights and the collective good aspect of rights as well as the concept of ius standi. Further, the rationale of "collective complaints" is analyzed by contemplating in detail the incentive structure for individuals, groups and NGOs to bring a complaint. Those incentives differ, depending on whether an individual right or a collective right (in a broad sense) is infringed, and depending on what the procedural requirements and the costs of complaints are in the given context (II.). A detailed analysis of the respective human rights treaties concerning substantive provisions and standing provisions follows (III.). The different human rights systems are analyzed from this perspective (IV.), while the final section concludes (V.).

\section{Theoretical Description of the Problem}

IHRL is an organic whole in its functioning. Nevertheless, one may analyze constituent parts of it in order to draw conclusions for the potential of enhancement of the whole system. In order to put the procedural provisions analyzed in this article into a broader contextual framework, several variables conducive to bringing complaints are presented:

(1) Socio-economic circumstances, the rule of democracy or autocracy, educational level, general access to the legal system and knowledge of the IHRL system are important factors. These variables capture the general environment of potential victims and their access to the international legal system.

18 See also Alan O’Neil Sykes, “The Economics of Public International Law”, University of Chicago Law \& Economics, Olin Working Paper No. 216 (2004), at 5. B. vii, available at:

$<$ http://papers.ssrn.com/paper.taf?abstract_id=564383>. 
(2) The expected compliance of the respondent state enters as well into the calculus of a potential complainant. ${ }^{19}$ Therefore, the probability of compliance with the decision needs to be taken into account: this depends on the binding nature of the decision (including the binding nature in the respective national law) and the means to supervise compliance with the judgment. It may make a difference if compliance monitoring is done by a political body or by the judicial body itself. As a rule, it can be hypothesized that the better the monitoring and enforcement system, the greater the incentive to bring a complaint. Institutional provisions for monitoring and enforcing the execution of judgments certainly merit further research, but cannot be dealt with here, as the focus lies on the legal institutions providing access to human rights bodies.

(3) The general framing of the decisions, that is, the way judicial bodies formulate the duty of the respondent state in the operative part of the judgment may be important for a potential complainant. Judicial bodies can only declare violations, may include damages or may encompass more or less general measures the state has to take, including the challenging of national statutes or practices. Generally speaking, it can be hypothesized that if there are reparations to be paid for the violation found or precise measures to be taken (such as a release from prison), this will be conducive to claims. The higher the reparations or the more precise the dictum, the more likely a complaint will be brought. ${ }^{20}$

(4) The expected length of the proceedings may be important as "justice delayed is justice denied" - to cite an old saying. Thus, a potential complainant will take the length of the proceedings into account.

(5) The composition of the judicial body may be of importance. If, e.g., the complainant considers that the proceedings are political or that the members do not understand the nature of violations in specific countries, she may be less inclined to complain. Here, it is assumed that this does not play a great role in comparison with having the possibility of review of a national human rights infringement.

(6) In important parts of the world, the fear of negative consequences or repercussions for a named victim or her lawyers inflicted by state authorities may be taken into account if the individual victim is named. ${ }^{21}$ Those expected consequences amount to non-monetary expected costs.

19 Nevertheless, the complainant might be satisfied with the declaration of „injustice“ by an international body. Therefore, it can be expected that victims complain even if they do not necessarily expect compliance of the state.

20 One might even consider introducing "punitive” damages as a penalty for systemic or especially gross violations. See Opinion No. 209/2002 on the Implementation of the Judgments of the European Court of Human Rights, adopted by the Venice Commission at its 53rd Plenary Session (13-14 December 2002), Doc. No. CDL-AD (2002) 34, available at: <www.venice.coe.int/docs/2002/CDL-AD(2002)034-e.asp\#_ftnref1>, at para. 78 et seq., where "astreintes" (fines for delays in the performance of a legal obligation) are considered. Nevertheless it should be noted that reparations, as all monetary compensation, may be only of secondary importance for complainants. See e.g. Bruno Frey, Not Just for the Money. An Economic Theory of Personal Motivation, 1997; Ernst Fehr/Armin Falk, "Psychological Foundations of Incentives", European Economic Review 46 (2002), 687-724.

21 See e.g. I/A Court H.R., Exceptions to the Exhaustion of Domestic Remedies. Advisory Opinion OC-11/90 of August 10, 1990 (Series A, No. 11), at para. 32. and 35. 
(7) The monetary costs, e.g. the requirement to be represented by a lawyer, legal aid and cost recovery provisions will be considered by a potential complainant. It may be hypothesized that legal aid and cost recovery provisions are conducive to claims. Here, one may also include the possibility of amicus curiae briefs of NGOs as well as NGOs or legal firms acting as representatives pro bono as those usually help the applicant without charge and thus reduce the costs. One may also include the requirement of exhaustion of local remedies, as the exhaustion requirement augments the costs of bringing a claim to the international body.

(8) The nature of the rights infringed.

(9) The requirement of ius standi.

The focus of this article remains with the ex ante possibility of bringing a complaint and the incentives to do so and therefore will deal with (6), (7), (8) and (9); the other variables are mentioned in that context, but are not analyzed in depth.

In order to capture the problem theoretically, independently of the provisions found de lege lata, the relationship between the substantive provisions of human rights treaties including their collective good aspect, that is the nature of the right infringed (1.) and the procedural provisions of ius standi (2.) will be analyzed in the following. After that, the incentive structure to bring a complaint will be analyzed in detail (3.), taking into account also the variables (6) and (7).

\section{Collective Good Aspects of International Human Rights Complaints}

International human rights litigation is rarely only a matter of private concern or interests affecting only the parties. Even narrow issues might have a broad human rights impact. ${ }^{22}$ Although the establishment of IHRL was motivated by the search for individual redress, it was stressed from the beginning that individual complaint mechanisms also contribute to securing respect for the objective obligations which are incumbent upon the States Parties to the relevant conventions. Three functions of complaints can therefore be identified: (1) correcting the infringement of an individual or group right (private benefit), (2) controlling the legality of public action, and (3) the development of IHRL through precedents.

The first function (private benefit) is at first sight a private good but may also contain a collective or club good element, depending on the nature of the substantive provision. IHRL usually conveys substantive rights and correspondingly procedural rights only to the individual. In IHRL, the discussion on the nature of rights is mostly anchored on three issues: (i) the problem of defining individual human rights versus group and peoples' rights, ${ }^{23}$ (ii) the traditional differentiation between civil and political rights on the one hand and economic, social and cultural

22 Shelton, supra note 8 , at 614.

23 See for an overview on peoples rights Ian Brownlie, “The Rights of Peoples in International Law”, in: James Crawford (ed.), The Rights of Peoples, 1988, Oxford, 1-16. For a more abstract discussion, see Peter Jones, “Human Rights, Group Rights, and Peoples’ Rights”, Human Rights Quarterly 21 (1999), 80-107. 
rights on the other hand as well as (iii) the distinction between positive and negative rights. ${ }^{24}$ While acknowledging the importance of this (theoretical) discussion on the nature of rights, it is not taken up here as it does not influence the argument of this paper. I define rights, for the purpose of the paper, as legally recognized interests which are to be found on a continuum from individual to collective interests. ${ }^{25}$ None of the described categorizations of rights mentioned above capture this dimension. To clarify the argument, one might imagine the right to life, which is based on a purely individual interest and the right to self-determination, which is based on a right which bundles individual interests to a collective interest. ${ }^{26}$ The collective good character is greater for rights with a collective aspect: If all the (normatively relevant) benefit is with the individual, there is no collective good element in effectively defending the right, whereas if others are violated simultaneously by the nature of the right (e.g. self-determination), the individual complaint conveys a benefit to all of them. In that case, the right per se already possesses an inherent public good aspect. Further examples are religious-freedom type rights which may be conceived as rights with individual aspects, such as the right of freedom to worship but may have collective interest aspects as well, such as the interest of a religious group in maintaining respect for its holy sites. Furthermore, there are several (individual) rights which can only be exercised collectively: democracy (i.e. the right to vote ${ }^{27}$ ), freedom of assembly and association, and minority rights. Especially minority rights can to a large extent only be exercised collectively, such as the right to speak one's own language, schooling in one's own language, and participating in cultural life. The same applies e.g. for landuse rights of indigenous people, who usually even own those rights collectively. ${ }^{28}$ But even if a purely individual right, such as the right to physical integrity of an individual, is under consideration, most often these too are de facto not restricted to one individual, rather extend to many others in the same factual situation, as in the case of industrial pollution, ${ }^{29}$ or noise from airports ${ }^{30}$ and all systemic or large-scale violations. Thus,

24 See Karel Vasak, “Les Différentes Typologies des Droits de L’Homme”, in: Emmanuelle Bribosia (ed.), Classer les Droits de l'Homme, 2004, Bruxelles, 11-23 for an overview of the classifications. For the positive/negative right distinction, see also Cordula Dröge, Positive Verpflichtungen der Staaten in der Europäischen Menschenrechtskonvention, 2003, Berlin et al., at 4-10.

25 Following Rudolf v. Jhering, Der Kampf um's Recht, 1880, Wien, and Joseph Raz, The Morality of Freedom, 1986, Oxford, at 181 et seq., who base their rights theory on interests.

26 Collective rights are usually defined as those rights whose beneficiary is the collectivity per se rather than its individual members. They are rights which can be exercised by a group itself. See Harriet Ketley, "Exclusion by Definition: Access to International Tribunals for the Enforcement of the Collective Rights of Indigenous People”, International Journal on Minority and Group Rights 8 (2001), 331-368, at 331, and Rainer Hofmann, "Minority Rights: Individual or Group Rights? A Comparative View on European Legal Systems”, German Yearbook of International Law 40 (1997), 356-382, at 359.

27 See for example the right to vote of Turkish Cypriots, Case of Aziz v. Cyprus (Appl. No. 69949/01), Eur. Ct.H.R. Judgment of 22 June 2004, available at:

$<$ http://cmiskp.echr.coe.int/tkp197/view.asp?action=html\&key=35547\&portal=hbkm\&source=external\&tabl e=285953B33D3AF94893DC49EF6600CEBD49>.

28 Group rights or minority rights are usually associated with ethnic or cultural characteristics and thus oftentimes with territorial rights and regional autonomy, which makes them politically so delicate. It is not the intention here to address those issues. For the purpose of the argument, it suffices to acknowledge that certain interest may be de iure or de facto only awarded to a group.

29 See Case of López Ostra v. Spain (Appl No. 16798/90), Judgment of 09 December 1994, 303 Eur. Ct. H.R. at 41 (1995), Case of Guerra and others v. Italy (Appl No. 14967/89), Judgment of 19 February 1998, 1998-I, No. 64 Eur. Ct. H.R at 210, where the right to information in environmental issues was granted the first time and Case of Öneryildiz v. Turkey (Appl. No. 48939/99), Eur. Ct.H.R. Judgment of Grand Chamber of 30. Nov. 2004, available at: 
many human rights thus have aspects of a collective or club good, either because the nature of the right per se includes a collective aspect or because de facto many individuals are affected, even if they are dealt with in human rights treaties as individual rights.

We will now turn to the second function, i.e. controlling the legality of public action. This comes in two forms: (1) Control of legality has the function of deterrence, i.e. general prevention. Individual complaints are a legal governance strategy which comes into effect ex post, that is, after the state acted. Nevertheless, the "threat potential" of complaints may also take effect ex ante as the state actors can be expected to be rational in the sense that they anticipate the risk of future sanctions. ${ }^{31}$ The mere possibility of control provides incentives for the states and can thus be expected to lead to an altogether lower level of negative externalities caused by human rights abuses. (2) The control of legality applies with respect to the case which is submitted, that is the decision may result in changes to internal legislation and administrative practices. ${ }^{32}$ Depending on the nature of the violation found, the individual or general measures to be adopted by the respondent State may be categorized, generally, as follows: (i) the need to amend legislation; (ii) the need to take appropriate action in respect of agents of the State; (iii) the need to encourage an appropriate interpretation of domestic legislation and/or jurisprudence; (iv) the need to reopen domestic proceedings. ${ }^{33}$ This applies equally to the infringement of rights through an individual administrative or judicial measure applying the law as well as to the infringement of rights by the law itself. In the latter case, the collective good character of a decision is even greater, as the domestic law as such is declared in violation of the respective treaty and therefore the case has, if the decision is properly implemented, consequences for the entire country, that is de facto inter omnes. Decisions regarding administrative or judicial practices which are deemed an infringement of rights may also have an important collective good aspect, as e.g. overlong criminal hearings, especially if they are systemic.

The third function of complaints regards the setting of a legal precedent. In all the cases where the dicta of the court are published, the legal aspect of the case is relevant both for the individual case at hand (irrespective of the substantive right) and for the development of IHRL with a view to similar future cases. Most treaties are viewed as "living instruments”, 34 and as IHRL develops by

<http://cmiskp.echr.coe.int/tkp197/view.asp?action=html\&key=41373\&portal=hbkm\&source=external\&tabl $\mathrm{e}=$ 285953B33D3AF94893DC49EF6600CEBD49>.

30 See Case of Hatton and others v. The United Kingdom (Appl. No. 36022/97), Judgment of 8 July 2003, [GC], 2003-VIII Eur. Ct. H.R at 191, which dealt with noise from the Heathrow airport.

31 Sanctions are to be understood in a broad sense, including reputational effects.

32 The ECtHR states as follows: "A finding by the Court of a violation of the Convention has often led the respondent State, and sometimes even other Contracting States, to take general measures to comply with the decision in question and the higher domestic courts to adapt their case-law. In some cases, the reference of a case to the Court has of itself prompted or expedited amendments to legislation and regulations or changes in the case-law." It publishes those cases, which are deemed to have effects of a general nature separately under $<$ http://www.echr.coe.int/Eng/EDocs/EffectsOfJudgments.html>.

33 See Opinion No. 209/2002 on the Implementation of the Judgments of the European Court of Human Rights, supra note 20, at para. 20. See for an overview of the obligations indicated by the HRC, see Dominic MacGoldrick, The Human Rights Committee: its Role in the Development of the International Covenant on Civil and Political Rights, 1994, Oxford, at 152 et seq.

34 This is the view of the ECtHR, see Tyrer v. the United Kingdom, Judgment of 25 April 1978, 26 Eur.Ct. H.R (ser. A), at 15-16, at para. 31 and subsequent case-law. 
complaints, those cases provide a collective good. ${ }^{35}$ The dicta might be relevant not only for the respective respondent state, but also for all other State Parties of the relevant treaty. It might also be relevant for other individuals in the same factual situation. Furthermore, case law of IHRL bodies also becomes increasingly important for other IHRL bodies and national courts. ${ }^{36}$ Nevertheless, the value of a case as precedent may vary depending on the case at hand: if there is well developed case-law, it is smaller, whereas if it takes up a new legal or factual question, it is greater.

Thus, to the extent that an individual complaint leads to the enforcement of an individual right this is at first sight a private good. But taking a case to court always also entails a voluntary contribution to the provision of a collective good. The actual degree depends on (i) the nature of the substantive right, (ii) on the alleged violation (general-abstract law or individual measure), as every judicially established violation of an individual's human right carries simultaneously the effect of controlling the legality of state action, be it legislative, judicial or administrative, and (iii) on the value of the case as precedent. Thus, a bundling of goals takes place as a private good (for the complainant) and a collective good (for other individuals and states) are provided simultaneously. It follows that potential gains (from winning a case) cannot be completely internalized $^{37}$ whereas potential losses (from losing a case) are completely internalized. The rational complainant will take into consideration only the provision of the private good. It might be that the private benefit is a sufficient incentive in order to bring a complaint. But in many cases it can be assumed that the private benefit is not enough to bring a case - there might be a gap between the private and the social optimal level of complaints. ${ }^{38}$ An individual alone has systematically less incentives to take a case to court than e.g. an organization or a group representing a large number of potential beneficiaries of a court decision as in the latter case, the optimal level is more aligned than in the former case, especially concerning the first function.

\section{Provisions of lus Standi}

Having argued that bringing complaints to IHRL bodies amounts to the provision of a collective good, the crucial question arises: what kind of incentives for complaints are generated by the procedural provisions of ius standi in the respective treaties?

International human rights treaties focus to a wide extent on individual rights in a substantive sense. This focus is also reflected in the procedural provisions of human rights treaties, which in most cases allow only for individual standing. ${ }^{39}$ Nevertheless, owning a right and having ius standi are two different issues, i.e. the ownership of a right and the competence to assert it by a

35 Such was also the argument in Jhering, supra note 25, at 49: „Who fights for his law, fights for the law“ (my translation).

36 The collective good character of precedents becomes ever more important in a „global jurisprudence“, which we find emerging through cross-border citing and citation of IHRL courts (the ECtHR is the mostly cited international tribunal). See Anne-Marie Slaughter, A New World Order, 2004, Princeton, at 79 et seq.

37 Internalization is defined as the process of reversing an externality, see supra note 14.

38 See for a more general discussion Steven Shavell, "The Level of Litigation: Private versus Social Optimality”, 19 International Review of Law and Economics 19 (1999), 99-115.

See infra, at III. 
judicial process are not identical. ${ }^{40}$ Rights and ius standi do not need to be identically derived. They are logically independent. ${ }^{41}$

Ius standi, or the capacity to file a complaint, may be differentiated into further subcategories, which are sometimes not clearly distinguished, neither in court decisions nor in the literature. There is firstly the (procedural) capacity to be a party to a complaint and secondly the (substantive) victim requirement, that is, the question of whose right is allegedly infringed. Following this distinction, it is possible to distinguish abstractly different forms of ius standi with a view to the victim requirement: ${ }^{42}$

First, an individual substantive right may be enforced by an individual complaint (including juridical persons); thereby an individual or entity claims an own injury: an individual right is claimed by its owner in his own name. All IHRL treaties provide that possibility.

Secondly, an individual substantive right is claimed by its owner in his own name, but there are several individuals in a similar situation, which all claim their own right in their own name. This would be the typical case of a joinder. Either the individuals already file the complaint together or the judicial body may decide to form a joinder. The different individual cases are bundled together, but in spite of possible legal and factual similarities, the legal consequences in each case are singular, including the admissibility requirements. ${ }^{43}$

Thirdly, substantively there can be group rights or a bundle of individual rights (such as Art. 27 CCPR as interpreted by the HRC) amounting to group rights. Here, all members of the group are infringed in a substantive right. The right bearer can be the group as a whole or the members of a group individually. A minority right or a group holding a right, e.g. landuse, would be a case in point. Theoretically, those may be claimed by either the whole group per se or by one representative on behalf of a group, that is, procedurally either the group as such may bring a complaint, or one representative claims an own right and simultaneously the individual rights of named and identified individuals or at least of an identifiable group. Usually, all individuals being part of the group have to give their consent, but that does not need to be the case. Judicial bodies sometimes can accept petitions from one representative, e.g. the chief of a tribe. Here, the legal consequence applies to all individuals within the group. Those kinds of complaints will be named "group complaints".

40 See for a broad discussion concerning minorities and indigenous people and ius standi Anna Meijknecht, Towards International Personality. The Position of Minorities and Indigenous Peoples in International Law, 2001, Antwerpen, Chapter II and V, esp. at 175 et seq.

41 Hersch Lauterpacht, International Law and Human Rights, 1950, London, at 54 et seq.

42 For an examination of the evolution of the notion of "victim" (including the potential victim) in the international law of human rights, see Antônio Augusto Cançado Trindade, "Co-Existence and CoOrdination of Mechanisms of International Protection of Human Rights”, Recueil des Cours/Académie de Droit International de La Haye 202 (1987), 9-435, at 262-283.

43 Most Rules of Procedure of the UN treaty bodies allow for that and equally those of the regional human rights treaties. 
Fourthly, there is the institution of class action, ${ }^{44}$ known in US-American procedural law ${ }^{45}$ and also used in human rights cases under the Alien Tort Claims Act. ${ }^{46}$ It is nonexistent in IHRL de lege lata. Here, an individual brings an action defending an own individual right but simultaneously compromises in the action in principle all the individuals infringed in that same substantive right so that the individual rights of all class members are enforced. Explicit consent by the class members is not in any case necessary and the individuals do not need to be named in the first place. Class action litigation requires i.a. commonality, that is, the proposed class must raise common questions of law or fact and typicality, that is, a nexus between the applicant and the underlying class. ${ }^{47}$ The decision applies equally to all members of the class, that is, the legal and factual consequences are bundled together, thereby creating judicial economy. Class actions are especially suited for large-scale violations. Class actions were an invention of equity mothered by the practical necessity of providing a procedural device so that their mere numbers would not disable large groups of individuals, united in interests, from enforcing their rights. As stated in 32B Am Jur 2d Federal Courts $\S 1782$, the "aggregation of individual claims in the context of a classwide suit is an evolutionary response to the problem of injuries unremedied by the regulatory action of government. Where it is not economically feasible to obtain relief within the traditional framework of a multiplicity of small individual suits for damages, aggrieved persons may be without any effective redress unless they may employ the class-action device.” Nevertheless, the incentive to bring a class action depends very much on the fee structure for lawyers, as those usually initiate class actions.

Fifthly, it is possible to enforce objective law (on behalf of the public interest) without a victim or where the victim is not necessarily identified. Furthermore, infringement of subjective rights may be claimed by a complainant who is not identical with those whose right was infringed upon and has no special relationship with the victims (actio popularis). In Roman law, an actio popularis was an action that could be brought by an individual on behalf of the public interest. ${ }^{48}$ This amounts to (i) objective enforcement of law $^{49}$ by an individual action ${ }^{50}$ (actio popularis in sensu

44 See generally from a law and economics perspective Charles Silver, "Class Actions - Representative Proceedings”, in: Boudewijn Bouckaert/Gerrit De Geest (eds.), Encyclopedia of Law and Economics, 2000, Cheltenham, 194-240.

$45 \quad$ Federal Rules of Civil Procedure 23 (a): "Prerequisites to a Class Action. One or more members of a class may sue or be sued as representative parties on behalf of all only if (1) the class is so numerous that joinder of all members is impracticable, (2) there are questions of law or fact common to the class, (3) the claims or defenses of the representative parties are typical of the claims or defenses of the class, and (4) the representative parties will fairly and adequately protect the interests of the class.” The right of a litigant to employ this rule as the provision for class actions in US-Federal Courts is only a procedural right, that is, the rule does not abridge, enlarge, or modify any substantive right or alter basic jurisdictional requirements.

46 See Beth van Schaack, “Unfulfilled Promise: The Human Rights Class Action”, University of Chicago Legal Forum (2003), 279-352.

47 See William J. Aceves, “Actio Popularis? The Class Action in International Law”, University of Chicago Legal Forum (2003), 353-402, at 358, 399.

48 Ibid., at 356. The ICJ understood the concept in that way in South West Africa (Ethiopia v. South Africa; Liberia v. South Africa) (1960-1966), Second Phase Judgment, ICJ Reports (1966) 6 at 47, para. 88: “(T)he argument amounts to a plea that the Court should allow the equivalent of an "actio popularis", or right resident in any member of a community to take legal action in vindication of a public interest".

49 The notion "objective law" refers to the entirety of the law regardless of whether it confers a subjective right on somebody. In constitutional law, for example, state organization is objective law, whereas basic rights are subjective law (and objective law). 
strictu) or to (ii) a distinction of complainant and victim, that is the rightholder (even unknown or only identifiable) and the complainants are not identical and have no special relationship. This kind of complaint is known in IHRL only for inter-state complaints. ${ }^{51}$

Sixthly, it is possible to enforce the substantive right of an infringed group or individual by a complaint filed by an NGO, where again the right holder and the complainant are not identical, ${ }^{52}$ so called "altruistic" NGO complaints. Here, the NGO acts as complainant on behalf of the victims, claiming another ones' substantive right. This has to be distinguished from so called "egoistic" NGO complaints whereby the NGO claims its own right as a corporation and it also has to be distinguished from those cases where NGOs help victims bringing a complaint as representatives, that is, NGOs act similar to lawyers. Altruistic NGO complaints are mostly called actio popularis, by the juridical bodies as well as in the literature. Nevertheless, there are important differences. Actio popularis in its strict sense does not require any victim - the complaint may solely allege the incompatibility of national laws or practices with international law. It is therefore a complaint in abstracto challenging objective law. In contrast, NGO complaints are mostly brought on behalf of identified or at least identifiable victims, thereby claiming somebody's else rights in its own name. Nevertheless, complaints by NGOs may also be called actio popularis if the NGO does not need to identify or name the victims. Furthermore, in an actio popularis anybody may bring a claim, whereas usually for an NGO to be admitted as a complainant, the NGO needs to be registered. Therefore, NGO complaints are usually filtered via the process by which NGOs are registered. ${ }^{53}$

If NGOs file complaints as representatives of victims, they usually do not take any money and help the victim with the complaint as counsel. Still, they need the victims to consent and the victims need to be named and act as complainants. Even if incentive problems of purely individual complaints, as described in 1), are mitigated if NGOs act as counsels, not all cases are covered as the prerequisite continues to be the individual victim requirement. In circumstances especially of large-scale violations when victims are too numerous or not identifiable or there is no access to justice, an altruistic NGO complaint may be the only way of brining a case.

Class Complaints, NGO complaints and actio popularis shall be called "collective complaints" hereinafter, because those categories dispense either with the requirement of an individual victim in total or with the requirement of an individual victim being directly involved in the complaint. In IHRL, they are rare de lege lata.

50 See Aceves, supra note 47, at 356 et seq., where he considers erga omnes obligations to be an issue for actio popularis.

51 So called "abstract applications" with the character of an actio popularis, See for the ECHR, van Dijk/van Hoof, supra note 8 , at 40 . Those complaints are seldom used, see supra note 8.

52 See for the role of NGOs in IHRL Shelton, supra note 8; Caroline Schwitter Marsiaj, The Role of International NGOs in the Global Governance of Human Rights, 2004, Zürich, especially for Africa Kwadwo Appiagyei-Atua, "Human Rights NGOs and their Role in the Promotion and Protection of Rights in Africa”, International Journal on Minority and Group Rights 9 (2002), 265-289, especially for the Americas Bertha Santoscoy, La Commission Interaméricaine des Droits de l’Homme et le Développement de sa Compétence par le Système des Pétitions Individuelles, 1994, Paris, at 57 et seq. and Jo M. Pasqualucci, The Practice and Procedure of the Inter-American Court of Human Rights, 2003, Cambridge, at 100 et seqq. For differences between class action and actio popularis, see Aceves, supra note 47, at 358 . 
Another ever more prominent form of participation of non-victims in international adjudication is the amicus curiae form. Hereby, NGOs, expert or other interested parties may suggest to a judicial body matters of law and fact within their knowledge. ${ }^{54}$ Amici Curiae have the advantage to allow participation not only on the basis of an infringed right but on the basis of a general interest, to protect unrepresented persons or the public interest. On the one hand, an amicus brief is generally less costly and time consuming than intervention or starting a complaint. It may also generate a broader spectrum of information for the judicial body otherwise not available and thus produce a collective good. On the other hand, amici are not entitled to any compensation of costs, which makes the expenses of the amicus non-recoverable. ${ }^{55}$ As most international human rights judicial bodies require a victim attribute for standing, the amicus curiae possibility is a useful complement for participation. Nevertheless, amicus curiae can only come in once a complaint is brought - thus the gate-keeping function of "standing” is upheld. In Part III it will be mentioned if the respective international human rights treaties allow for amicus curiae, but the incentives of filing amicus briefs for non-victims will not be separately discussed. ${ }^{56}$

\section{The Rationale for "Collective Complaints" in International Human Rights Law}

As spelled out above, there are several procedural possibilities to deal with the infringement of individual rights and collective/group interests. De lege lata, in IHRL the infringement of a subjective right corresponds mainly with an individual complaint possibility, if at all. Even if collective or group interests are infringed by the state, it is in most cases only the individual who may bring a complaint. Those legal provisions generate incentives or disincentives for potential complainants. Thus, from a rational-choice perspective, it is not deemed satisfactory to look only at legal provisions; rather it is also necessary to analyze in detail the factual incentive structures for launching complaints in the first place. We will focus here on the incentive structure with a view on ius standi on the one hand and the nature of the right infringed on the other hand, turning to the detailed analysis of an individuals' incentive to complain.

An individual will complain only if his expected cost of doing so is less than his expected benefit (expected net benefit), ${ }^{57}$ that is, she will complain if and only if the expected net benefit is posi-

54 Some systems require registration for NGOs in order to have consultative status, see e.g. ECOSOC Res. 1996/31, Consultative relationship between the United Nations and non-governmental organizations, Resolutions and Decisions of the Economic and Social Council, 1996, Supp. No. 1, U.N. Doc. E/1996/96 (1997), at 53. See for details Schwitter Marsiaj, supra note 52, at 8 et seq.

55 See for more details Shelton, supra note 8, at 611 et seq., for the advantages and disadvantages of amicus curiae.

56 For an overview of participation by amici in the ICJ, the ECtHR, the ECJ and the IACHR, see Shelton, supra note 8, favoring a broad nongovernmental amicus participation and for a broad overview of NGO participation, see Schwitter Marsiaj, supra note 52.

57 It is difficult and debatable to put numbers on the value of rights, but for the sake of simplicity let's assume that a right with a value assigned to it of 100 Euro was infringed, yet if it will cost 150 Euro to bring a complaint, the individual will do nothing because the costs of recovery exceed the benefit. A rational complainant will not spend the money. Even if it were to cost 50 Euro to get an award of 100 Euro, choosing not to act may still be justified by an individuals' "rational apathy". Although the benefits exceed the cost, a rational complainant would rather let someone else enforce rights on their behalf and thus "free-ride", 
tive. The greater (smaller) the expected benefit, the more likely it is that a complaint will (not) be brought. From this description, one can note that a complaint is more likely to be brought, (i) the lower the cost, (ii) the greater the likelihood of winning and (iii) the greater the complainants' probable reward, provided he wins. ${ }^{58}$

The individual incentives to launch a complaint can be identified theoretically by assuming rational behavior of the individual. ${ }^{59}$ The incentive structure represents that of an assumed average individual. The benefit of an individual in launching a complaint is narrowly defined as the private benefit. Any additional benefit an individual may enjoy by - simultaneously - providing a collective good such as the controlling of the legality of state behavior or by setting a precedent is neglected. Furthermore, effects on other individuals within the same situation or group are not assumed to be relevant for the individual benefit calculus. ${ }^{60}$ It follows that if a complaint has only a private aspect, internalization is perfect, whereas if a complaint has collective good aspects, the incentive structure is such that the collective good element will be underprovided, as the individual does not include those in her calculus. Also, the expected net benefit of a proceeding is subjectively estimated; whether an individual will bring a complaint or not depends on subjective individual loss of benefit by infringement, that is, preference intensity of the individual may make an important difference. Individuals may not be entirely rational in calculating the probability of winning a complaint. From behavioral economics it is known that under certain circumstances people are overoptimistic while under other circumstances loss aversion is eminent. ${ }^{61}$ Thus, there may be a selection effect between those who have standing and those who actually bring a complaint.

The benefit upon winning is defined by the benefit derived from the private relief by the award of the judicial body, being the benefit created by the bodies' decision in favor of the complainant. The benefit derives from reparation, through the fulfillment of the required action by the state or through mere satisfaction by a declaratory judgment. The private benefit will generally be smaller if the judicial body issues only a declaratory judgment.

particularly if the right has a huge collective good aspect. For a general economic analysis on litigation, see Steven Shavell, Foundations of Economic Analysis of Law, 2004, Cambridge (Mass.), Chapter 17.

58 A more formal presentation concerning benefit would look as follows: $E$ (B) $=f$ (importance of right infringed, likeliness to win). The award itself is subject to other variables, such as the nature of the award (e.g. just a statement or view of a violation or awarding damages or injunctions), the legally binding force of the decision and the probability of enforcement of the decision, see supra at II.

59 An individually felt need for "justice" or "truth" in a case concerning that same individual is considered to be part of the individual preference function. It is not disputed that other than rational considerations may play a role in bringing a complaint. There might be individuals who act irrationally in the classical rational-choice sense, bringing a complaint in spite of negative expected net benefit. This might have several reasons: bounded rationality, insufficient information, and there might also be a „Michael Kolhaas"-effect, that is, people might complain because of a general experience of injustice. However, this does not apply for the average complainant, who is primarily relevant for designing laws. For simplicity, it is assumed that the complainant is risk-neutral; would she be risk-averse or risk-seeking, the curve would be convex respectively concave.

60 In the literature, this is often called non-altruistic behavior which means that only the benefit which is directly reaped by the individual counts.

61 Daniel Kahnemann, "New Challenges to the Rationality Assumption”, Legal Theory 3 (1997), 105-124; Daniel Kahnemann/Amos Tversky, "Prospect Theory: An Analysis of Decisions under Risk", Econometrica 47 (1979), 312-327. 
By assumption, the expected benefit varies in accordance with the graveness of the infringement of the right. The more fundamental the right, the more important is the expected gain for that individual. ${ }^{62}$ It is assumed that the infringement of a subjective right of a complainant is - considering absolute benefit - in most cases a stronger impairment than the non-observance of a collective interest or a group right. This is plausible as the subjective rights of the individual are normally those which are the essence of his civil and political rights, such as the right to life, liberty and trial (habeas corpus). If a complaint is brought by an individual on behalf of a minority or a group, the complainant enjoys the positive outcome only in proportion to his legal interest, that is, only pro rata. This applies equally to those cases where the individual complainant alleges as a substantive right an individual right, but knows that there are other individuals in the same situation (e.g. environmental cases, e.g. cases involving the right to water, ${ }^{63}$ or cases where the right may only be exercised collectively, e.g. right to association), as well as in those cases, where de facto a genuine minority right is at stake, e.g. Art. 27 CCPR. Individual benefit from internalization therefore originates either from the judicial acceptance of an individual claim or by judicial acceptance of collective interests, but in the latter case only pro rata. There are thus two reasons why individual complaints for collective interests are less likely: (i) in cases where group rights or collective interests are at stake, the individual benefit from internalization is either absolutely lower, as no habeas corpus rights are infringed which leads to lower expected net benefit (negligible individual infringements or non-observance of collective interests) and (ii) even if the benefit of internalization is - from an absolute viewpoint - the same, the incentive to complain is lower due to the classical collective good phenomenon of free-riding, that is, the individual will wait for others to provide the good.

The expected costs of an individual complainant are, from the point of view of an individual, typically higher for individual complaints than for groups or mass litigation, as the individual has to bear all costs - monetary and non-monetary - alone in the former situation. Even if it might be the case that costs will be higher in collective complaints as there are more facts to be considered, the average cost for the individual is pro rata lower in collective complaints.

Non-monetary costs begin for many citizens with the search for legal advice, ${ }^{64}$ lack of knowledge of IHRL, and problems of communication with juridical institutions. Oftentimes, the educational, economic, and territorial situation is not conducive for bringing a claim and the costs for doing so range from immense to prohibitive. Additionally, the complainant or her lawyers might fear repercussions by state actors or paramilitary forces in some countries.

62 Of course, there might be human rights violations which cannot be compensated by material damages. Still, the assumption holds that winning a case provides for satisfaction and benefit.

63 The UN Committee on Economic, Social and Cultural Rights stated in its General Comment No. 15, U.N. Doc E/C.12/2002/11 (2003) that access to water is a human right and a public commodity fundamental to life and health. It also stipulates that water, like health, is an essential element for achieving other human rights, especially the rights to adequate food and nutrition, housing and education.

64 This is certainly true for individual complaints, but in class action cases the initiative to complain might be taken by a law firm or an NGO. 
The monetary costs can be divided in the costs of legal advice (though in all IHRL bodies legal representation is not required, but advisable), the costs of exhausting local remedies ${ }^{65}$ and the expenses relating to the court proceedings, such as traveling and reimbursing the expenses of witnesses. The expected costs of a complaint then are a function of the expected outcome of the trial, if the costs are allocated depending on the outcome of the trial. But with the exception of the ECtHR, ${ }^{66}$ legal fees are not explicitly recoverable in case of winning and, again with the exception of the ECtHR, there is no legal aid provision for those parties who cannot afford to bring a petition otherwise. Nevertheless, other judicial bodies may include legal costs in damages in case those are awarded. ${ }^{67}$ In all other cases, the potentially unrecoverable costs of petitions even in the case of winning may deter meritorious complaints. This is especially the case if the judicial body just states a violation of the respective treaty without recommending reparations. The Human Rights Committee (HRC) ${ }^{68}$ and the ECtHR ${ }^{69}$ themselves stated for national legal cost recovery that high expected costs may deter complaints in human rights cases. It can be hypothesized that legal aid and explicit cost recovery provisions lead, ceteris paribus, to higher amounts of complaints. ${ }^{70}$ That said, there are many cases where law firms act pro bono, thus alleviating the costs substantially. ${ }^{71}$ The same applies if NGOs bring cases either as altruistic claims or on behalf of the victim as representatives. Nevertheless, subsidizing meritorious complaints through

65 All treaties or Rules of Procedure of the regional courts as well as of the UN treaty based system require the exhaustion of local remedies, unless those are not effective or unreasonably prolonged. Usually the judicial bodies dispense with this requirement if local remedies take to long or are deemed to be ineffective. The exhaustion of local remedies requirement does not affect the argument of this article as the complaints can always be gathered on the international level, even if on the national level only individual complaints are allowed.

66 The ECtHR holds the practice that only legal costs and expenses found to have been actually and necessarily incurred and which are reasonable as to quantum are recoverable under Article 41 of the Convention. This may include domestic legal costs actually and necessarily incurred to prevent or redress the breach of the Convention. Nevertheless, the Court may include higher costs, even if they were not submitted, if it deems that those costs were in fact incurred. See ECtHR Case of Aziz v. Cyprus, supra note 27, at para. 46.

67 For a critique concerning the UN treaty based system, see Murat Metin Hakki, “The Silver Anniversary of the UN Human Rights Committee: Anything to celebrate?”, International Journal of Human Rights 6 (2002), 85-102, 93.

68 See See Anni Äärelä and Jouni Näkkäläjärvi v. Finland, Communication No. 779/1997 (4 February 1997), U.N. GAOR, 57th Sess. , Supp. 40, Vol. II, at 117, U.N. Doc A/57/40 (Vol. II) (2002) concerning Sami Minority rights at para. 7.2.

69 E.g. in the case of Airey v. Ireland (Appl. No. 6289/73), 32 Eur. Ct. H.R. (ser. A) (1980), (Judgment of 11 September 1979), the ECtHR held that although the Convention does not explicitly provide for a right to free legal assistance in civil cases, in some circumstances it may oblige the state to provide legal aid in civil disputes. Article 6.1 ECHR may require the states to provide free legal assistance when such assistance proves indispensable for securing an effective access to court either because legal representation is mandatory under the domestic law or because of the complexity of the procedure or the case. There is no reason why that argument should not be extended to IRHL bodies.

70 That may be one reason why the ECtHR has the most applications. I am well aware though that funds for legal aid are missing within the UN-treaty based system and also for the other regional bodies, see Cesare P.R. Romano, “International Courts and Tribunals: Price, Financing and Output”, in: Stefan Voigt et al. (eds.), International Conflict Resolution. Conferences on New Political Economy 23, 2005, Tübingen, forthcoming for the budget comparison of the Inter-American Court and the ECtHR.

71 See e.g. Laurence R. Helfer, "Overlegalizing Human Rights: International Relations Theory and the Commonwealth Caribbean Backlash Against Human Rights Regimes”, Columbia Law Review 102 (2002), 1832-1909, at 1877, Fig. 4, who finds that in the representation of death row defendants in petitions filed from Commonwealth Caribbean Nations with Human rights tribunals, over $80 \%$ were represented by lawyers, mostly pro bono. 
legal aid and explicit cost recovery could help especially in less spectacular cases where NGOs or pro bono working law firms do not take the case.

Generally speaking, individual costs will be higher for individual complaints and joinders because costs are not necessarily shared between different complainants ${ }^{72}$ and because one can assume that group or collective complaints allow for hiring more expensive, but better law firms. Likewise, group or mass litigations tend to raise media attention and therefore are attractive for NGOs or pro bono experts to get involved. The expected costs of the complaint vary according to the different allocation rules and the practices of the judicial bodies.

The different incentives of the individual will now be scrutinized in detail. If individual rights of an individual are infringed, it will be ceteris paribus more apt to file a complaint than if a group right or collective interests are infringed, since the loss of benefit by an infringement is assumed to be greater if an individual (habeas corpus) right is violated and thus the private benefit from the expected court decision will also be correspondingly greater. Furthermore, in a case where a purely individual right is at stake, the court decision may be to a greater extent a private good (except for setting a precedent and providing for the legality of state behavior, which are irrelevant for the individual calculus). In this case, only where the individual expects costs to be very high, the individual will not complain. If the individual is represented by an NGO or a law firm pro bono, the (monetary) cost risk is usually shifted to those: this may be the reason why a lot of cases brought to international judicial bodies show that pattern.

In contrast, if the claim is about group rights or rights with collective aspects, the court decision is to a greater extent a collective good, as there are a huge number of individuals affected. There are huge incentive obstacles to provide a collective good, as the individual, if she does not have a very high preference for the good, will be inclined to take the position of a free rider and wait for others to provide the collective good. This explains also why actiones populares by individual complainants are less probable (NGOs have different incentives) - and thus the fear of a court overflow by actiones populares by individuals is not well founded. ${ }^{73}$ In any case, there are other legal mechanisms to deter frivolous complaints. ${ }^{74}$

Regarding joinders initiated by an individual, that is, complaints alleging many individual violations on a larger scale, one has to differentiate between initial individual costs of gathering the other alleged victims for bringing a complaint (pre-trial costs) and the general individual costs as described above. The initial hurdle for forming a joinder is high in the beginning, until the initiating individual finds some form of cooperation, which is difficult due to collective action and informational problems. The costs are higher in cases where there is no defined group (unorgan-

72 If the joinder is formed by the complainants, cost sharing usually occurs by taking one lawyer. In case the joinder is mandated by the judicial body that does not apply. But in all joinders costs of experts and witnesses may be divided.

73 Of course, "political entrepreneurs" or gripers may still bring complaints, but those should be few and can always be dismissed.

74 Abuse provisions, which fulfil a filtering function because they allow for a declaration of inadmissibility, are found in all treaties analyzed here. 
ized groups), that is, individuals do not know each other than in cases where the group is organized, e.g. tribes. Once a group of individuals has gathered to bring a complaint though, the individual costs decrease compared with an individual complaint, as the total costs (especially monetary costs) may be shared among those bringing the complaint. ${ }^{75}$ Still, the individual may not take the initiative, as it is providing a collective good by the gathering of other concerned individuals. Here again, the free-rider-effect may come into play.

As group complaints allow for complaints by individuals on behalf of the group, the total costs may be divided among the group and the gathering costs are not too high, as not every individual needs to file a complaint separately. Yet, even if a complaint is successful, the benefit is not privatized, but is collectivized for the benefit of the group, i.e. for all other concerned individuals. The collective good provided is thus extended to all the group members. The relative share of benefit of the complainant is thus diminished in group complaints. It is thus rather unlikely that an individual will sue on behalf of a group or minority on rational grounds, especially if the cost risk stays with the individual. This argument becomes weaker, however, if this individual has a (political) stake in the well-being of the group, e.g. as a chief of an ethnic minority.

In contrast, if the costs of a complaint for one single individual are abated through the possibility of a "collective complaint", that is NGO complaints or class actions, ${ }^{76}$ the probability of a complaint being launched rises. Class actions are more effective than alternatives, such as joinders because in joinders the individual still acts alone in court and the court decision generally takes effect only inter partes, including the decision on costs. ${ }^{77}$ In class action cases, the decision applies to the whole class and costs are shared among class members. Class actions are therefore especially suited for complaints concerning laws or systematic and large-scale violations. To lower the costs and thus augment the net benefit for those cases is exactly the rationale of procedural provisions such as class actions in the United States. For class actions to be effective on the international plane, a look at the incentive structure for lawyers concerning their fees is necessary as without someone being inclined to gather the class and initiate the action, the collective action problem still arises.

The same applies for altruistic NGO complaints being brought on behalf of an individual or a whole group. One may ask why NGOs have an incentive to bring a complaint in the first place. The costs may be high for NGOs, but their incentive to bring a complaint lies in their function and the possibility of publicity, including the possibility of fund-raising. Furthermore, NGOs,

75 Graphically, this could be shown in a coordinate plane, depicting on the $\mathrm{x}$-axis the number of individuals required for the complaint and on the $y$-axis the costs for the initiating individual. Whereas the costs for the initiating individual will rise up to the quorum, it will fall once the group is gathered. The course of the curve will differ, depending how difficult it is for the individual to gather other individuals willing to act.

76 Those might be brought by law firms which act pro bono. Those law firms usually act pro bono for reputational effects and those would be greater with class actions. Thus, a monetary incentive is not necessary.

77 When the class is not large, joinder of all members as named parties may nevertheless be more practical. For a broad discussion, see David Rosenberg, "Avoiding Duplicative Litigation of Similar Claims: The Superiority of Class Action vs. Collateral Estoppel vs. Standard Claims Market”, Discussion Paper No. 394 of the John M. Olin Center for Law, Economics, and Business, Harvard Law School (2002), available at: <http://www.law.harvard.edu/programs/olin_center/papers/394_rosenberg.htm>. 
especially those specialized in IHRL, may incur smaller costs than individuals as they usually have legal expertise within the organization and legal representation is generally not required in IHRL. But also NGOs will be cautious not to bring frivolous suits as they easily destroy their reputation and thus their possibility of raising funds. For the unlikely case that frivolous complaints by NGOs are brought, they may be deterred by other means than closing the standing gate in principle. Both, NGO and class actions may also diminish non-monetary costs, that is, the problem of access to justice and repercussions by state actors as the individuals need not be named.

Holding the infringement of an interest or right equal (ceteris paribus), it may thus be concluded that if there is a legal provision for "collective complaints", the probability of a complaint is greater, as the expected net benefit of a "collective complaint" is rising due to the lower expected costs. The possibility of "collective complaints" increases the probability of judicial control of non-observance of rights with collective aspects and in situations where bringing an individual complaint is too costly. Not only is the individual incentive problem mitigated as net expected benefit increases with collective complaints, but also judicial economy demands a bundling of those cases, as the individual standing requirement can result in a multitude of individual actions.

To sum up: "Collective complaints" diminish the de iure and therefore also the de facto hurdles which are an obstacle to the effective control of the human rights records of states by individual complaint mechanisms. The rational abstinence of the individual is mitigated through these legal mechanisms. From a rational-choice point of view, individual complaints can be expected to be few, especially in those cases where they provide a collective good through the nature of the right. "Collective complaints" are perceived as a device to empower individuals by affording them access to justice by courts and as a device for controlling the legality of state action. Furthermore, they might have a greater impact on compliance with judgments or views as they usually attract greater publicity and thus render IHRL more effective.

\section{Human Rights Treaties Provisions - a Legal Gap}

We will now turn to the legal provisions found in those international treaties which allow for the possibility of individual complaints. Each of these treaty regimes functions differently and against a different legal and socio-economic background. Nevertheless, it is possible to concentrate on those variables identified earlier in the article and compare them in view of the hypothesis put forward here. Under the UN-treaty based system, treaties which allow for individual complaints are: the International Covenant on Civil and Political Rights $\left(\mathrm{CCPR}^{78}\right.$ ) (provided that the state is a party to the First Optional Protocol), the Convention on the Elimination of All

78 Opened for signature Dec. 16, 1966, 999 U.N.T.S. 171 (entered into force Mar. 23, 1976); and First Optional Protocol to the International Covenant on Civil and Political Rights (hereinafter: FOP), opened for signature Dec. 16, 1966, 99 U.N.T.S. 302. As of 09 June 2004, it had 152 State Parties. The First Optional Protocol to the CCPR had 105 State Parties as of 09 June 2004. 
Forms of Racial Discrimination $\left(\mathrm{CERD}^{79}\right)$ (provided that a declaration has been made in accordance with Art. 14), the Convention against Torture $\left(\mathrm{CAT}^{80}\right.$ ) (provided that a declaration has been made in accordance with Art. $\left.22(1)^{81}\right)$, the Convention on the Elimination of All Forms of Discrimination against Women $\left(\mathrm{CEDAW}^{82}\right.$ ) (provided that the state is a party to its Optional Protocol). The International Covenant on Economic, Social and Cultural Rights (CESCR) ${ }^{83}$ and the Convention on the Rights of the Child (CRC) ${ }^{84}$ do not provide for individual complaints procedures and will therefore not be dealt with. The International Convention on the Protection of the Rights of All Migrant Workers and Members of Their Families $\left(\mathrm{CMW}^{85}\right)$ provides for an individual complaints procedure, which however has not yet entered into force. ${ }^{86}$

The following regional instruments also allow for individual complaint mechanisms: the European Convention for the Protection of Human Rights and Fundamental Freedoms (ECHR ${ }^{87}$; mandatory under the 11th Protocol ${ }^{88}$ ), the American Convention on Human Rights ${ }^{89}$ (Art. 44; mandatory concerning complaints to the Commission) and the African Charter on Human and Peoples' Rights ${ }^{90}$ (Art. 55; mandatory concerning complaints to the Commission). An overview

79 Adopted by G.A. Res. 2106A (XX), U.N. GAOR, XX, Supp. No. 14, at 47, U.N. Doc A/6014 (entered into force Jan. 4, 1969). As of 09 June 2004, it had 169 State Parties, of which 45 States recognized the competence under Art. 14 CERD. The Committee could start working under Art. 14 only as soon as 10 State Parties made a declaration under Art. 14. That happened Dec. 3, 1982. The Committee began its work under Art. 14 in 1984.

80 Adopted Dec. 10, 1984, 1465 U.N.T.S. 113 (entered into force June 26, 1987). As of 09 June 2004, it had 136 State Parties.

81 As of 13 May 2005, 57 State Parties have made the respective declaration.

82 Adopted Dec. 18, 1979, 1249 U.N.T.S. 13 (entered into force Sept. 3, 1981). As of 18 March 2005, it had 180 State Parties and as of 7 January 2005, there were 71 State Parties to the Optional Protocol, adopted by G.A. Res. 4, U.N. GAOR, 54th Sess. , Supp. 49, Vol. I, at 4, U.N. Doc A/54/49 (Vol. I).

83 Opened for signature on Dec. 16, 1966, 993 U.N.T.S. 3 (entered into force Jan. 3, 1976). As of 9 June 2004 , it had 149 State Parties. The only international measure for monitoring supervision of the ICESCR is a state reporting procedure. For an overview on the already long discussion about the justiciability of the CESCR, see Michael J. Dennis/David P. Stewart, “Justiciability of Economic, Social, and Cultural Rights: Should there be an International Complaints Mechanism to Adjudicate the Rights to Food, Water, Housing, and Health?”, American Journal of International Law 98 (2004), 462-515 with further references.

84 Adopted Nov. 20, 1989, 1577 U.N.T.S. 3 (entered into force Sept. 2, 1990). As of 09 June 2004, it had 27 State Parties.

85 Adopted by G.A. Res. 158, U.N. GAOR, 45th Sess., Supp. 49 A, at 261, U.N. Doc. A/45/49 (Vol. I), (entered into force July 1, 2003). Today, there are a total of 26 ratifications.

86 The individual complaint procedure will only enter into force when a minimum of ten State Parties to the CMW have made the necessary declaration under Art. 77 (1), see Art. 77 (8). No state made a declaration in that respect as of 10 May 2005. Art. 77 allows only for communications from or on behalf of individuals, not groups, Art. 77 (1), which is - from the point of view of this article - a mistake as discrimination most of the times involve a huge collective good aspect.

87 Adopted Nov. 4, 1950, 213 U.N.T.S. 221(entered into force Sept. 3, 1953).

88 Protocol No. 11 to the Convention for the Protection of Human Rights and Fundamental Freedoms, restructuring the control machinery established hereby, adopted May 11, 1994, 33 I.L.M. 943 (entered into force Nov. 1998).

89 O.A.S. Treaty Series No. 36, 1144 U.N.T.S. 123, 9 I.L.M. 673 (entered into force Jul. 18, 1978). As of 01 September 2004, 25 American nations out of 35 OAS members have ratified or have adopted the Convention.

90 Adopted June 27, 1981, OAU Doc. CAB/LEG/67/3 rev. 5, 21 I.L.M. 58 (1982), entered into force Oct. 21, 1986. The Charter has been ratified by all the OAU/AU member States. 
on the procedural provisions is provided in the figure below, which is explained in more detail in the following. ${ }^{91}$

\begin{tabular}{|l|c|c|c|c|c|c|c|c|c|}
\hline \multicolumn{1}{|c}{ Treaty body } & CCPR & CERD & CEDAW & CAT & ECtHR & $\begin{array}{c}\text { African } \\
\text { Court }\end{array}$ & $\begin{array}{c}\text { African } \\
\text { Com. }\end{array}$ & $\begin{array}{c}\text { Amer. } \\
\text { Syst. } \\
\text { Com. }\end{array}$ & $\begin{array}{c}\text { Amer. } \\
\text { Syst. } \\
\text { Court }\end{array}$ \\
\hline $\begin{array}{l}\text { Complaint } \\
\text { mandatory }\end{array}$ & -- & -- & -- & -- & + & -- & + & + & -- \\
\hline Binding decision & -- & -- & -- & -- & + & + & - & -- & + \\
\hline $\begin{array}{l}\text { Initiation } \\
\text { motu proprio }\end{array}$ & -- & -- & + & + & -- & -- & + & + & -- \\
\hline $\begin{array}{l}\text { Individual } \\
\text { complaint }\end{array}$ & + & + & + & + & + & + & + & + & + \\
\hline Legal Persons & -- & -- & -- & -- & + & + & + & $+(\mathrm{J})$ & $+(\mathrm{J})$ \\
\hline Joinder & $+(\mathrm{J})$ & + & + & $+(\mathrm{J})$ & + & + & + & + & + \\
\hline Group Complaint & -- & + & -- & -- & -- & + & + & + & + \\
\hline Class Action & -- & -- & -- & -- & -- & -- & -- & -- & -- \\
\hline $\begin{array}{l}\text { Victim } \\
\text { requirement }\end{array}$ & + & + & + & + & + & + & -- & + & + \\
\hline Potential Violation & + & + & + & + & + & + & + & + & + \\
\hline Actio Popularis & -- & -- & -- & -- & -- & $?$ & + & -- & -- \\
\hline Altruistic NGO & -- & -- & -- & -- & -- & + & + & + & + \\
\hline $\begin{array}{l}\text { Complaint } \\
\text { without consent } \\
\text { of victims }\end{array}$ & -- & -- & $(--)$ & -- & -- & + & + & + & + \\
\hline Legal aid & -- & -- & -- & -- & + & -- & - & -- & -- \\
\hline $\begin{array}{l}\text { Legal cost } \\
\text { recovery (apart } \\
\text { from damages) }\end{array}$ & -- & -- & -- & -- & + & -- & -- & -- & -- \\
\hline
\end{tabular}

Fig. 2: Standing requirements in IHRL

$\mathrm{J}=$ Not in Text, but in Jurisprudence

91 See for short overviews also Comparative summary of existing communications and inquiry procedures and practices under international human rights instruments and under the United Nations system, Report of the Secretary-General, E/CN.4/2005/WG.23/2 of 22 November 2004, Commission on Human Rights at its 61th session, available at:

<http://daccessdds.un.org/doc/UNDOC/GEN/G04/166/07/PDF/G0416607.pdf?OpenElement>

and Comparative summary of existing communications and inquiry procedures and practices under international human rights instruments and under the Charter of the United Nations, Report of the SecretaryGeneral, U.N. Doc E/CN.6/1997/4 of 21 January 1997, Commission on the Status of Women at its 41th session, 10-21 March 1997, available at: <http://www.un.org/documents/ecosoc/cn6/1997/ecn61997-4.htm>. 


\section{The UN-Treaty Based System}

Since 1945, numerous steps have been taken in the development of a comprehensive international human rights system. The Universal Declaration of Human Rights ${ }^{92}$ represented the first step in the development of this system and includes a broad range of civil and political rights on the one hand and economic, social and cultural rights on the other hand. Nowadays, there is a wide variety of monitoring and enforcement mechanisms within the U.N. human rights system. ${ }^{93}$ Unlike Charter-based bodies, which apply to all UN Member states, treaty-based bodies supervise states parties' compliance with a particular human rights treaty. The so-called treaty-based procedures, established under the major U.N. human rights treaties, all include reporting procedures, individual complaint procedures, inter-state complaints procedures, and inquiry procedures. The committees also issue "general comments", ${ }^{94}$ which are interpretations of the provisions of the human rights treaties clarifying the obligations of State Parties. Furthermore, in the early 1990s the treaty bodies started adopting conclusions and recommendations after examining the specific country reports. This practice, along with the increasing acceptance of the role of NGOs as information-providers to the treaty bodies, has resulted in a relatively objective system of treaty monitoring. The treaty bodies are composed of independent experts elected in their individual capacities, although proposed by governments.

Some of the procedural features are common to all treaty-based procedures, which allows to treat them together at that point: None of the views given by the respective committees are binding for the respective state. All procedures require for admissibility that all available domestic remedies have been exhausted. ${ }^{95}$ Furthermore, the cost provisions are uniform: None of the treaty-based

92 G.A. Res. 217A (III), U.N. GAOR, 3rd Sess., at 71, U.N. Doc. A/810 (1948).

93 The complaint mechanisms under individual treaties are complemented by complaint procedures before the Commission on Human Rights and the Commission on the Status of Women. See for the relationship between those mechanisms: Nigel S. Rodley, "United Nations Non-Treaty Procedures for Dealing with Human Rights”, in: Hurst Hannum (ed.), Guide to International Human Rights Practice, 1999, Ardsley, 6184. The two procedures, involving political bodies composed of State representatives, have a different focus from complaints under the international treaties, which provide individual redress through quasi-judicial mechanisms. Under the best-known procedure, which became known as the "1503 procedure" from the number of the resolution of the Economic and Social Council (ECOSOC) by which it was established in 1970, the Commission on Human Rights receives on a confidential basis information on gross and systemic violations of human rights from victims, NGOs, and others in specific countries. Complaints to the Commission focus on more systemic patterns and trends of human rights violations and may be brought against any country in the world.

94 See the compilation of General Comments at <www.unhchr.ch/tbs/doc.nsf/0/ca12c3a4ea8d6c53c1256d500056e56f?Opendocument>.

95 E.g. for the CCPR, see Art. 5 para. 2 (b) FOP and rule 90(f) of the Rules of Procedure of the HRC in accordance with Article 39 of the CPPR; United Nations, International Human Rights Instruments, Compilation of Rules of Procedure. Adopted by the Human Rights Treaty Bodies, Note by the Secretariat, U.N. Doc HRI/GEN/3/Rev.1 (2003), available at:

<http://daccessdds.un.org/doc/UNDOC/GEN/G03/414/12/PDF/G0341412.pdf?OpenElement> (hereinafter: HRC Rules of Procedure).

But unlike the other treaties, e.g. Art. 5 para. 2 (a) FOP, Art. 14 of the CERD does not require that the same matter is not being examined under another procedure of international investigation or settlement. See for the matter of forum shopping in IHRL Laurence R. Helfer, "Forum Shopping for Human Rights”, University of Pennsylvania Law Review 148 (1999), 285-400, at 304 et seq. 
individual complaint procedures provides for legal aid. ${ }^{96}$ Furthermore, the claimant does not recover his costs even if the communication is successful. Even though the treaties do not require legal representation before the committees, ${ }^{97}$ in practice, alleged victims have been represented by lawyers, law professors and NGOs. In case this was pro bono representation, monetary costs are low for the complainant. In all other cases, this substantially increases the costs in the calculation of the individual as even in case of success, the costs will be internalized, whereas the benefit will often be socialized (depending on the collective good character of the case). None of the committees will consider communications that are anonymous or which they consider to be an abuse of the right of submission of such communications. Whereas the former requirement may thus produce non-monetary costs to the complainants due to possible repercussions, the latter requirement allows for the filtering of frivolous claims - a filter which could also be used in case the standing requirements are extended, as suggested here. Apart from the very narrow definition of ius standi, especially the cost provisions might also be reasons why there are few complaints brought under the UN-treaty based mechanisms in view of the many countries and citizens covered by the treaties. ${ }^{98}$ It is appropriate to call them, just as inter-state complaints, thoroughly underused. Nevertheless, we will focus on the procedural provisions of ius standi and their relationship with the substantive provisions for reasons outlined above. ${ }^{99}$

\section{a. International Covenant on Civil and Political Rights (CCPR)}

The CCPR details the basic civil and political rights of individuals and peoples. Among the rights of peoples or collective rights are: the right to self-determination (Art. 1 (1)), the right to own, trade, and dispose of their property freely, and not to be deprived of their means of subsis-

96 See MacGoldrick, supra note 33, at 134, who also considers that this will most probably not change due to the fiscal situation of the UN.

97 Rule 90 (1) (b) of the HRC Rules of Procedure states that communications may be submitted by the individual itself or by his representative.

98 Under the CCPR, as of 3 May 2004, from a total of 1279 concluded communications, 362 were inadmissible, and from a total of 452 decided cases, in 349 cases a violation was found. There are 287 living cases. See $<$ www.unhchr.ch/html/menu2/8/stat2.htm>.

Under CERD, as of 31 March 2004, from a total of 33 concluded communications, thirteen were inadmissible, and from a total of ten decided cases, in five cases a violation was found. See $<$ www.unhchr.ch/html/menu2/8/stat4.htm>. All the cases were directed against developed countries (except for Australia, all countries were members of the EU) and most were communicated by non-citizens. The CERD Committee thus is rather dealing with cases of discrimination against foreigners, mainly concerning equality and non-discrimination issues in the area of economic and social rights. See Theodoor C. van Boven, "The Petition System under the International Convention on the Elimination of All Forms of Racial Discrimination. A Sobering Balance-Sheet”, Max Planck Yearbook of United Nations Law 4 (2000), 271287, at 281 and 285, who attributes the minimal use to lack of knowledge and information about the existence of Art. 14 CERD. He then refers to some human rights centers, which have taken notice.

Under CEDAW, as of 30 April 2004, from a total of two concluded communications, one was inadmissible, and in the other one a violation was found. See <http://www.un.org/womenwatch/daw/cedaw/protocol/decviews.htm>.

Under CAT, as of 14 May 2005, from a total of 242 concluded communications, 40 were inadmissible, 59 discontinued and from a total of 68 decided cases, in 25 cases a violation was found. There are 50 living cases. See <http://www.unhchr.ch/html/menu2/8/stat3.htm>.

99 See supra note 8. For an overview on different monitoring systems, see Gudmundur Alfredsson et al. (eds.), International Human Rights Monitoring Mechanisms. Essays in Honour of Jakob Th. Möller, 2001, The Hague. 
tence (Art. 1 (2)). Those rights are not justiciable in the view of the Human Rights Committee (HRC). ${ }^{100}$ Among the rights of individuals are the right to legal recourse when their rights have been violated (Art. 14), even if the violator was acting in an official capacity, the right to life (Art. 6), the right to liberty and freedom of movement (Art. 12), the right to equality before the law (Art. 26), the right to be presumed innocent till proven guilty (Art. 15), freedom of thought, conscience, and religion (Art. 18), freedom of opinion and expression (Art. 19), and freedom of assembly and association (Art. 21). The Covenant prohibits discrimination based on race, sex, color, national origin, or language (Art. 26). It also restricts the death penalty to the most serious crimes, guarantees condemned people the right to appeal for commutation to a lesser penalty, and forbids the death penalty entirely for people under 18 years of age at the time of the commission of the crime (Art. 6 (2) and (5)). In Art. 27, it protects persons belonging to ethnic, religious or linguistic minorities, by granting the rights, in community with the other members of the group, to enjoy their own culture, to profess and practice their own religion, or to use their own language. ${ }^{101}$ We thus find rights with strong public or club good character, especially Art. 27 CCPR.

For the purpose of the article, the admissibility ratione personae is of primary interest. ${ }^{102}$ Art. 1 of the FOP recognizes the competence of the HRC to receive and consider "communications from individuals subject to its jurisdiction who claim to be victims of a violation...”. The wording of the FOP thus only recognizes individual complaints. ${ }^{103}$ The victim cannot be a legal person, ${ }^{104}$ or a political party, ${ }^{105}$ or an NGO (on its own behalf). ${ }^{106}$ NGO communications are only permitted if the organization acts as a representative on behalf of an individual victim with his or

100 While the HRC has consistently reaffirmed self-determination as a right of all peoples, it has declined to receive individual complaints of violations of Art. 1. Self-determination is not a right cognizable under the FOP as the HRC stated in General Comment No. 23, A/49/40, Vol. I (1994), Annex V (p. 107-110); CCPR/C/21/Rev.1/Add.5, at para 3.1. See for an overview on self-determination in international law, Anne F. Bayefsky, Self-Determination in International Law, 2000, The Hague.

101 See Gaetano Pentassuglia, Minorities in International Law, 2002, Strasbourg. The protection of minorities was already pursued by the League of Nations, including a petition system by minorities, see for a brief historical overview, Buergenthal, supra note 4, at 10 et seqq. with further references.

102 See for overviews Tom Zwart, The Admissibility of Human Rights Petitions: the Case Law of the European Commission of Human Rights and the Human Rights Committee, 1994, Dordrecht, at 41-44 and Sarah Joseph et al., The International Covenant on Civil and Political Rights. Cases, Materials, and Commentary, 2004, Oxford, at 64-82.

103 This was a deliberate choice, see Manfred Nowak, U.N. Covenant on Civil and Political Rights: CCPR Commentary, 1993, Kehl, Art. 2 FOP, at 1, to avoid actiones populares by NGOs. Here again we find a confusion between actio popularis and NGO complaints.

104 A Newspaper Publishing Company v. Trinidad and Tobago, Communication No. 360/1989, UN GAOR 44th Sess., Supp. No. 40, U. N. Doc. (A/44/40) at 307 (1989) and A publication and a Printing Company v. Trinidad and Tobago., Communication No. 361/1989 (14 July 1989), UN GAOR 44th Sess., Supp. No. 40, U. N. Doc. (A/44/40) at 309 (1989). It is also inadmissible to file as a shareholder a communication on behalf of a company, see S. M. v. Barbados, Communication No. 502/1992, UN GAOR 49th Sess., Supp. No. 40, Vol. II, U. N. Doc. (A/49/40) at 318 (1994), at para 6.2. et seq. This might only be different if a right of a companies owner is directly infringed in an individual right. See Allan Singer v. Canada, Communication No. 455/1991, UN GAOR 49th Sess., Supp. No. 40, Vol. II, U. N. Doc. (A/49/40) at 155 (1994) at para. 11.2.

105 J. R. T. and the W. G. Party v. Canada, U.N. GAOR 38th Sess., Supp. No. 40, U. N. Doc (A/38/40) at 231 (1983), at para. 8 (a).

106 Erkki Hartikainen v. Finland, Communication No. 40/1978 (20 June 1983), U.N. GOAR, 38th Sess., U.N. Doc. Supp. No. 40 (A/38/40) at 255 (1983) where a school teacher brought a communication on his own behalf and in his capacity as General Secretary of an NGO. The latter was deemed inadmissible, see at para. 3. 
her consent. ${ }^{107}$ NGOs are thus allowed to assist complainants in their communications. ${ }^{108}$ Nevertheless, the HRC has been flexible on the wording and also allowed groups of individuals alleging a violation to file a joint communication with the HRC against States Parties to the FOP ${ }^{109}$ thus joinders are permitted. ${ }^{110}$ This allows for the grouping of communications, but without legal effect for the authors - i.e. this is just a provision for judicial economy, but does not represent a broadening of the standing requirement. More difficult is the question of group complaints as defined in this article. According to the jurisdiction of the HRC it is not clear whether individuals may be represented by a group, even if they did not consent to the communication personally. ${ }^{111}$ If this were the case, it could be assumed that some form of group complaint would be permitted, as views would entail a legal consequence for all members of the group as a whole. But the HRC always made clear that a group as such may not file a communication. This issue arose especially with respect to Art. 27 CCPR. The HRC views this article as establishing a right which is conferred solely on individuals belonging to minority groups and which is distinct from a group right. ${ }^{112}$ Therefore, only individuals may complain about the infringement of a minority right ${ }^{113}$ an institutional arrangement which is not conducive to complaints, as this may amount to a costly gathering of victims and thus constitutes an immense hurdle for bringing a case. Also, the free-rider argument applies forcefully in those constellations.

The victim requirement is generally indispensable for admissibility, thus neither altruistic NGO complaints on behalf of victims nor actio popularis ${ }^{114}$ is admitted. It requires that the complainant is personally and directly affected by the existing law, policy, practice, act or omission of the State Party; abstract violations are deemed insufficient. ${ }^{115}$ For a person to claim to be a victim of a violation of a right protected by the Covenant, she must show either that an act or an omission

107 In contrast with the ECtHR, an NGO cannot submit a communication to the HRC. See A group of associations for the defence of the rights of disabled and handicapped persons in Italy v. Italy, Communication No. 163/1984 (1984), U.N. GAOR 39th. Sess., U.N. Doc. Supp. No. 40 (A/39/40) at 197 (1984), at para. 6.2.

108 See e.g. Acuña Inostroza et al. v. Chile, Communication No. 717/1996, UN GAOR 54th Sess., Supp. No. 40, Vol. II, U. N. Doc. (A/54/40) at 313 (2000).

109 E. W. et al. v. Netherlands, Communication No 429/1990, UN GAOR 48th Sess., Supp. No. 40, Vol. II, U. N. Doc. (A/48/40) at 198 (1993), at para. 6.3.: „provided each of the authors is a victim within the meaning of article 1 of the Optional Protocol, nothing precludes large numbers of persons from bringing a case under the Optional Protocol. The mere fact of large numbers of petitioners does not render their communication an actio popularis, and the Committee finds that the communication does not fail on this ground.“

110 Rule 88 (2) HRC Rules of Procedure.

111 See Mikmaq Tribal Society v. Canada, Communication No. 78/1980, U.N. GAOR 39th. Sess., U.N. Doc. Supp. No. 40 (A/39/40) at 200 (1984), where the Committee seemingly accepted a communication from the Chief Captain of the Mikmaq tribal society, provided that he was able to produce a written authorization from the tribal Grand Council, but did not request that each member of the tribe submit a communication himself. Thus, a representing body of a defined group may suffice. Nevertheless, this case may be an exception insofar as tribal societies represent a closed group and are thus defined by ethnic or cultural criteria, whereas a class action does define the group by potential violation and is thus generally open ended.

112 General Comment No. 23, supra note 100, at 3.1.

113 Ominayak, Chief of the Lubicon Lake Band v. Canada, Communication No. 167/1984, U.N. GAOR 45th. Sess., U.N. Doc. Supp. No. 40 (A/45/40) at 1 (1990), at para. 32.1.

114 E. W. et al. v. Netherlands, supra note 109, at para. 6.4., where the HRC considered whether the authors are victims within the meaning of the OP. As this was not the case for nuclear threat in the Netherlands in the view of the HRC, it therefore found the communication inadmissible under Art. 1 of the FOP.

115 Nevertheless, there are some exceptions to that basic principle. There are some situations, where the HRC permitted a third party close to the victim to submit a communication. 
of a State Party has already adversely affected her enjoyment of such right, or that such an effect is imminent. It is not sufficient simply to challenge a law or State policy or practice abstractly. Nevertheless, this requirement is softened by the consideration of potential violations. The HRC received a number of communications, in which violations have not actually occurred but in which the author alleged they would occur in the future. This may be in case (1) that the concrete application of a law or practice constitutes a violation of CCPR, or (2) that the domestic legislation by its mere existence directly violates the petitioner's right. It should be noted that the character of a decision concerning the latter instance amounts to a greater collective good than the former, as we find an abstract revision of an existing law as such and therefore the obligation of the state to change the law, whereas in the former case, the consideration of the HRC might just amount to the review of an application of the law. The HRC has been rather reluctant in admitting cases, where a violation by the law is not directly imminent and held hypothetical events not permissible. ${ }^{116}$ Future violations must be foreseeable and imminent. This is mostly the case, where the law is imminent to be applied, e.g. in cases of extradition or death penalty. ${ }^{117}$ The HRC also considered an individual to be a victim if a law or practice is applicable in such a way that the alleged victim's risk of being affected is more than a theoretical possibility, i.e. if the victim is already affected by the law even in the absence of any individual measure of implementation. ${ }^{118}$ The HRC also admitted communications which challenged domestic legislation, which directly violated the petitioner's rights by its mere existence. ${ }^{119}$

In spite of the sometimes broad interpretation of the victim requirement, the restriction concerning groups and NGOs seems overcautious, especially in the light of the substantive provisions of the CCPR, that is Arts. 1 (self-determination), 18 (religion), 21 (freedom of assembly), 22 (freedom of association), and last but not least Art. 27 (minority rights), which are all rights that have per se a collective good aspect as they may only be exercised within a group. True, the gate to standing may be opened further by gathering all potential victims, but depending on the circumstances that may amount to a de facto impossibility, as it will be either impossible or too costly for the individual to gather all those affected. Furthermore, this restrictive interpretation by the HRC excludes all peoples, minorities, churches, parties, and legal persons. ${ }^{120}$

Concerning the enforcement measure, the HRC often indicates what an appropriate remedy would be, like for instance the payment of compensation or the release from detention. In the event of a failure by the State Party to take appropriate steps, the case is referred to a member of the HRC, the Special Rapporteur on Follow-up of Views, for consideration of further measures to be taken. The Special Rapporteur may, for example, issue specific requests to the State Party

116 See A. R. S. v. Canada, Communication No. 91/1981, U.N. Doc. CCPR/C/OP/1 at 29 (1984), at para. 5.1. et seq.

117 Charles Chitat Ng v. Canada, Communication No. 469/1991, UN GAOR 49th Sess., Supp. No. 40, Vol. II, U. N. Doc. (A/49/40) at 189 (1994).

118 See S. Aumeeruddy-Cziffra and 19 other Mauritian Women v. Mauritius, Communication No. 35/1978, U.N.GAOR 36th Sess., U.N. Doc. Supp. No. 40 (A/36/40) at 134 (1981), at para. 91.

119 See A group of associations for the defence of the rights of disabled and handicapped persons in Italy v. Italy, supra note 107 , at para. 6.2 .

120 With a similar view, Nowak, supra note 103, at 5 et seq. 
or meet with its representatives to discuss the action taken. ${ }^{121}$ Unless, exceptionally, the information on implementation is suppressed, it is published together with the action taken by the Special Rapporteur in an annual report on follow-up. ${ }^{122}$

\section{b. International Convention on the Elimination of Racial Discrimination (CERD)}

The CERD contains several undertakings for states (Art. 2, 6, 7 CERD), but does also include individual civil and political as well as economic, cultural and social rights in Art. 5. Among the latter are the right to work, to free choice of employment, to just and favorable conditions of work, to protection against unemployment, to equal pay for equal work, to just and favorable remuneration; the right to form and join trade unions; the right to public health, medical care, social security and social services; the right to education and training and the right to equal participation in cultural activities. Some of those rights may only be collectively exercised, e.g. the right to freedom of peaceful assembly and association, some aspects of the freedom of religion and the right to form and join trade unions. Furthermore, in most of the cases, discrimination issues are affecting a whole group of individuals discriminated against. In the sense of this article, we may thus speak of a collective right.

Compliance with the CERD is supervised by the Committee on the Elimination of Racial Discrimination (CERD Committee, established under Art. 8 of CERD), i.a. by receiving petitions from individuals and groups of individuals claiming violations of their rights under the CERD (Art. 14) ${ }^{123}$ In contrast to complaints under the FOP to the CCPR or the CAT, complaints under CERD may explicitly be brought not only by individuals but also by groups of individuals; joinders are thus explicitly permitted. ${ }^{124}$ Like all committees, the CERD Committee holds on to the victim requirement and does not permit actio popularis or NGO complaints, if the latter cannot show that it or a member of it is a potential victim under CERD. ${ }^{125}$

121 Rule 95 of the HRC Rules of Procedure.

122 Rule 97 of the HRC Rules of Procedure. The views of the HRC are usually made public (Rule 96).

123 See generally for the compliance mechanisms under the CERD Rüdiger Wolfrum, " International Convention on the Elimination of All Forms of Racial Discrimination”, in: Eckart Klein (ed.), The Monitoring System of Human Rights Treaty Obligations, 1998, Berlin, 49-69.

Art. 14 (1) CERD.

125 The potential victim notion follows the jurisdiction of the HRC. See e.g. The Documentation and Advisory Centre on Racial Discrimination v. Denmark, Communication No. 28/2003, U.N. GAOR 57th. Sess., U.N. Doc A/57/18 (2002), Annex III.B, p. 134-140 (2002) dealt with an alleged discriminatory job advertisement by a Danish firm. The Committee held that it did not exclude the possibility that a group of persons representing, for example, the interests of a racial or ethnic group, may submit an individual communication, provided that it is able to prove that it has been an alleged victim of a violation of the Convention or that one of its members has been a victim, and if it is able at the same time to provide due authorization to this effect (at 6.4.). While the relevant section of the Danish law prohibits discrimination of all persons of non-Danish origin in job advertisements, whether they apply for a vacancy or not, it does not automatically follow that persons not directly and personally affected by such discrimination may claim to be victims of a violation of any of the rights guaranteed in the Convention. Any other conclusion would open the door for popular actions against the relevant legislation of States parties (at 6.7.).

More extensive though in A. Koptova v. Slovakia, Communication No. 13/1998, UN GAOR 55th Sess., Supp. No. 18, U. N. Doc. (A/55/18) at 137 (2000) where the CERD Committee was of the view, contrary to the State Party, that the author could be considered a "victim" within the meaning of article 14, paragraph 1 , of the Convention, since she belonged to a group of the population directly targeted by the laws in question, 
The extension of ius standi to groups may be understood as a tribute to the collective good character of the right against discrimination. As the right against discrimination has collective aspects because even if discrimination is established concerning just one individual, it is usually discriminated against as a member of a group, be it an ethnic group or being of foreign nationality. This club good character or collective good character makes the possibility of joinders meaningful. Nevertheless, as discrimination has quite a huge collective good aspect, from a rationalchoice perspective it can be argued that the incentive to file a complaint is small for an individual due to free-rider incentives. Furthermore, joinders do not really reap cost reduction benefits to the complainants and thus do not augment substantially augment the expected net benefit of complaints.

\section{c. Convention on the Elimination of All Forms of Discrimination Against Women (CEDAW)}

The CEDAW ${ }^{126}$ defines discrimination against women in Art. 1 as “[...] any distinction, exclusion or restriction made on the basis of sex which has the effect or purpose of impairing or nullifying the recognition, enjoyment or exercise by women, irrespective of their marital status, on a basis of equality of men and women, of human rights and fundamental freedoms in the political, economic, social, cultural, civil or any other field.” It provides a basis for realizing equality between women and men through ensuring women's equal access to, and equal opportunities in, political and public life, including the right to vote and to stand for election, as well as education, health and employment, thus rights which are to be found also in the CESCR. The same collective good reasoning as under CERD concerning discrimination applies for CEDAW.

The CEDAW Committee recognizes communications submitted by four categories of authors under the Optional Protocol (OP): individuals; groups of individuals; authors on behalf of individuals; authors on behalf of groups of individuals. ${ }^{127}$ It may also initiate proceedings motu proprio. ${ }^{128}$ If a communication is submitted on behalf of one or more persons, their consent must either be proven or the author must present reasons in writing to justify the communication without consent of the alleged victim(s). ${ }^{129}$ The CEDAW Committee has not yet begun to interpret the circumstances that would justify acting without the consent of the alleged victim(s), as there has not yet been a complaint "on behalf” of a victim (as of May 16, 2005). The broadening of standing provisions under the OP is thus a step in the right direction. Even though complaints concerning discrimination matters may be called a club good for the group discriminated against, the OP provides only for the typical individual complaint or joinder complaint mechanism in-

even though the law in question never was applied to her, nor was going to be applied. She just belonged to the discriminated minority.

126 See for an overview of the history of the CEDAW, Andrew Byrnes/Jane Connors, "Enforcing the Human Rights of Women: A Complaints Procedure”, Brooklyn Journal of International Law 21 (1996), 679-797.

127 Art. 2 of the OP.

128 Art. 8 of the OP.

129 See Art. 68 of the Rules of Procedure of the Committee in Annex I of the Report of the Committee on the Elimination of Discrimination against Women, U.N. GAOR 56th Sess., U.N. Doc A/56/38 (2001). 
cluding the victim requirement, but not for class actions or NGO complaints. ${ }^{130}$ Nevertheless, the factual situation of many women in the world concerning their access to justice and their socioeconomic circumstances make the provision that communications may be filed on behalf of women very meaningful. The same reasoning applies for the initiation motu proprio by the CEDAW Committee, as monetary and non-monetary costs for women in many parts of the world may be too high to bring a communication.

\section{d. Convention against Torture and Other Cruel, Inhuman or Degrading Treatment or Punishment (CAT)}

The CAT bans torture under all circumstances. In particular, it defines torture, requires states to take effective legal and other measures to prevent torture, and declares that no state of emergency, other external threats, or orders from a superior officer or authority may be invoked to justify torture. It also forbids activities which do not rise to the level of torture, but which constitute cruel or degrading treatment. Even if the right not to be tortured is an individual right with no collective good aspect, the State Parties do need to undertake under CAT several obligations, such as putting in place legal measures to prevent torture and to provide adequate remedies, which have de facto inter omnes effect.

The Committee against Torture can receive and consider communications from individuals who claim to be victims of a violation of the provisions of the Convention by a State Party. ${ }^{131}$ It does not provide for communications of groups of individuals, but under rule 105 (4) of its Rules of Procedure, it may, if it deems appropriate, consider two or more communications together, thus joinders are allowed. Furthermore, the complaint may be submitted not only by the individual herself or by her relatives or designated representatives but also by others as author on behalf of an alleged victim when it appears that the victim is unable personally to submit the complaint, and when appropriate authorization is submitted to the Committee. ${ }^{132}$ Communications may thus be filed by NGOs as representatives on behalf of victims. ${ }^{133}$ It is nevertheless unclear, under what circumstances a complaint may be brought without the consent of the victim, e.g. by an NGO if the victim is not in a position to give consent. ${ }^{134}$ Under rule 62 of its Rules of Procedure, the Committee invites NGOs to submit information relevant to its activities and thus explicitly allows for amicus curiae briefs. As the prohibition of torture is a classical habeas corpus right, that is an individual right, it is appropriate to allow only for individual complaints. Nevertheless, torture is often systemic and thus NGO complaints or class actions may also be appropriate to alleviate the costs of brining complaints.

130 See for details Byrnes/Connors, supra note 126.

131 Rule 107 (a) CAT Rules of Procedure, U.N. Doc CAT/C/3/Rev.4 at 38, of 9 August 2002.

132 Art. 22 (1) CAT and Rule 107 (a) CAT Rules of Procedure.

133 See e.g Dhaou. Belgacem Thabti v. Tunisia, Communication No. 187/2001, UN GAOR 59th Sess., Supp. No. 44, U. N. Doc. (A/59/44) at 167 (2004), where the victim was represented by an NGO, which complained on behalf of him.

134 Michael O'Flaherty, "Individual Communications: The Convention Against Torture and the Convention on the Elimination of All Forms of Racial Discrimination”, in Sarah Pritchard (ed.), Indigenous Peoples, the United Nations and Human Rights, 1998, London, 116-128, at 120. 


\section{Regional Human Rights Treaties}

Europe, the Americas and Africa all have human rights conventions including judicial or quasijudicial systems of enforcement. On 15 September 1994, the Council of the League of Arab States adopted the fourth regional convention of human rights, the Arab Charter on Human Rights, which has not entered into force yet. ${ }^{135}$ Another Human Rights Convention was created by the Commonwealth of Independent States (CIS), ${ }^{136}$ which allows for individual complaints, ${ }^{137}$ but is not yet functioning. The regional systems operate under different socio-economic and legal circumstances which also explain to some extent the larger mandate of the African and the InterAmerican Commissions which are endowed with a broad mandate to monitor human rights practice. Nevertheless, the individual complaint mechanism is a crucial part of enforcing the respective treaties everywhere. Here again, as with the UN-treaty based system, it is appropriate to say that the systems are underused, ${ }^{138}$ with the exception of the ECtHR. ${ }^{139}$

135 But this Charter does only provide for state-reporting, not for individual complaints to a Human Rights Commission as other regional bodies (Art. 40, 41). The draft was revised and adopted by the Arab Standing Committee on Human Rights in January 2004.

136 The Convention on Human Rights and Fundamental Freedoms of the Commonwealth of Independent States (CIS Convention) was opened for signature on 26 May 1995 and entered into force on 11 August 1998. It has been ratified by Belarus, the Kyrgyz Republic, the Russian Federation and Tajikistan as of 15 May 2005.

137 Individual complaints are to be dealt with by a Commission, which issues non-binding views. Interestingly, Section III (1) of the CIS Convention empowers the CIS Commission to examine "individual and collective applications submitted by any person or non-governmental organisation concerning matters connected with human rights violations by any of the Parties and falling within the competence of the Commission”. The standing requirement is thus very broad.

138 Under the Inter-American system, the caseload of the IACHR is augmenting steadily: from 1997 with 458 applications it went up to 1080 in 2003. The year 2002 saw 4656 petitions, but from those 3763 petitions referred to the situation of the rights of persons affected by the banking measures "Corralito" in Argentina. The year 2004 saw 1329 petitions. Those are nevertheless few, in view of the human rights situations in the Americas. See Annual Report of the Inter-American Commission on Human Rights 2004; $<$ http://www.cidh.oas.org/annualrep/2004eng/chap.3.htm\#Statistics>. As for the court, the information is not provided in a statistical overview, but counting the information on its website, it has delivered 123 decision and judgments, 19 advisory opinions and ordered in 54 cases preliminary measures as of 14 May 2005; see $<$ http://www.corteidh.or.cr/juris_ing/index.html>.

There is different information concerning the cases before the African Commission. According to the University of Minnesota Human Rights Library, at

<http://www1.umn.edu/humanrts/africa/comcases/allcases.html>, as of 2002 there were 139 communications in total, of those 81 communications were brought by NGOs, few of them were filed on behalf of named individuals, the rest communicated alleged human rights violations without naming the victims. According to Frans Viljoen, “A Human Rights Court for Africa, and for Africans”, Brooklyn Journal of International Law 30 (2004), 1-66, at 6, from 1988 to 1992, the Commission received some 173 individual complaints, an average of less than 12 per year, and finalized some 90 communications between 1988 and 2001. According to Udeme Essien, "African Commission on Human and Peoples' Rights: Eleven Years After”, Buffalo Human Rights Law Review 6 (2000), 93-111, 105, as of 2000 the Commission had received 226 Communications. Of this number, 137 have been finalized and made public, 50 have been declared inadmissible, six resulted in friendly settlements, five were withdrawn, 88 were pending, 16 had been closed without decision, and one was a double registration.

139 It is generally recognized that the Court's excessive caseload (during 2004, some 40.943 new applications were lodged and at the end of that year, approximately 65.000 applications were pending before it) manifests itself in two areas in particular: i. processing the very numerous individual applications which are terminated without a ruling on the merits, usually because they are declared inadmissible (more than $90 \%$ of all applications), and ii. processing individual applications which derive from the same structural cause as an earlier application which has led to a judgment finding a breach of the Convention (repetitive cases following a so-called "pilot judgment"). A few figures will illustrate this. In 2004, there were some 20.350 applications declared inadmissible (or struck off the list of cases), and 830 applications declared admissible. Thus, the 


\section{a. European Convention on Human Rights (ECHR)}

The European System is the most developed regional human rights system. The Convention consists only of civil and political rights and is thus narrower in scope than the other regional human rights treaties. ${ }^{140}$ Recognition of the right of individual application was optional until the Protocol No. $11^{141}$ to the European Convention replaced the existing two-tier system of a part-time Court and a Commission by a single, full-time Court. The individual is now endowed with mandatory direct access to the ECtHR. Hence, unlike the other two regional human rights courts (the Inter-American and the African system), with the new system, private individuals have access to the ECtHR without an additional filter. Moreover, individuals can now, in limited circumstances, seek a re-hearing in a case decided by a ECtHR's Chamber (7 judges) before the ECtHR's Grand Chamber (17 judges). This is not possible under the other two regional human rights courts.

Art. 34 of the Convention states that the "Court may receive applications from any person, ${ }^{142}$ non-governmental organization or group of individuals claiming to be the victim of a violation by one of the High Contracting Parties of the rights set forth in the Convention or the Protocols thereto." The text thus allows explicitly for complaints by individual victims, by legal persons, and for joinders, ${ }^{143}$ yet always requiring the complainant to be an alleged victim. If there is a group of persons, all of them need to fulfil the victim requirement; there is thus no group complaint or altruistic complaint of an NGO in the name or on behalf of the individuals of that group. ${ }^{144}$ An NGO thus needs to be infringed in its own right in order to have standing. ${ }^{145}$ The

great majority of cases are terminated by inadmissibility or strike-off decisions (96\% of cases disposed of in 2004). In the remaining cases, the Court gave 718 judgments in 2004, some 60\% of which concerned repetitive cases. Since the beginning of the function of the European system, there have been 341.501 lodged applications and 117.058 taken decisions. See

<http://www.echr.coe.int/Eng/EDocs/2004SURVEY(COURT).pdf>, at para. 36.

140 But see the rights and the collective complaint mechanism under the European Social Charter, Oct. 18, 1961, 529 U.N.T.S. 89. See for an overview Robin R. Churchill/Urfan Khaliq, “The Collective Complaints System of the European Social Charter: An Effective Mechanism for Ensuring Compliance with Economic and Social Rights?”, European Journal of International Law 15 (2004), 417-456.

141 Convention for the Protection of Human Rights and Fundamental Freedoms, as amended by Protocol No. 11, supra note 88 .

142 Here person means natural person, including persons lacking legal capacity, e.g. minors. Jochen Abr. Frowein/Wolfgang Peukert, Europäische Menschenrechtskonvention: EMRK-Kommentar, 1996, Kehl, § 25, at 11 .

143 In spite of similar cases in systemic violation cases, the Court does not use joinders frequently. It rather decides on some of them as model cases and hopes that the state will comply. I would like to thank Rudolf Bernhardt, former president of the ECtHR for this information. This practice was confirmed recently in Case of Broniowski v. Poland, (Appl. No. 31443/96), Judgment of 22 June 2004, see at <http://cmiskp.echr.coe.int/tkp197/view.asp?action=html\&key=35541\&portal=hbkm\&source=external\&tabl $\mathrm{e}=$ 285953B33D3AF94893DC49EF6600CEBD49>.

144 See Zentralrat Deutscher Sinti und Roma and R. Rose v. Germany (App. No. 35208/97), Decision of 27 May 1997

<http://cmiskp.echr.coe.int/tkp197/view.asp?action=html\&key=3721\&portal=hbkm\&source=external\&table $=$ 285953B33D3AF94893DC49EF6600CEBD49>. See also Noël Narvii Tauira and 18 Others v. France (Appl. No. 28204/95), Decisions and Reports No. 83-A, at 112 et seq. (petitions against the French nuclear tests on Mururoa and Fangataufa Atolls in French Polynesia). For an overview see Zwart, supra note 102, at 45 et seqq.

145 For corporations that means that either share- or stakeholders may bring a petition, if they are personally affected by measures against the corporation or the corporation as such needs to be the victim. See for details Frowein/Peukert, supra note 142, § 25, at 23. 
Commission qualified e.g. Saami Villages as NGOs having standing, as the villages, not the individual Saamis, had the right under the respective Swedish law. ${ }^{146}$

The ECtHR requires that an individual applicant claims to have been actually affected by the violation he alleges, that is only applicants who can claim to be a victim of a violation can exercise the right of individual petition. Thus, an actio popularis is inadmissible; ${ }^{147}$ it does not permit individuals to complain against a law in abstracto simply because they feel that a legislative measures or administrative practices contravene the ECHR. ${ }^{148}$ In principle, it does not suffice for an individual applicant to claim that the mere existence of a law violates his rights under the ECHR; it is necessary that the law has been applied to his detriment. ${ }^{149}$ But Art. 34 entitles individuals to contend that a law violates their rights by itself, in the absence of an individual measure of implementation, if they run the risk of being directly affected by it. This compromises not only self-executing laws ${ }^{150}$ but also laws which are most probably applied to the petitioner. The ECtHR has accordingly accepted a potential threat to the applicant in the following cases: ${ }^{151}$ where the applicant was not in a position to demonstrate that the legislation he complained of had actually been applied to him because of the secret nature of the measures it authorized; ${ }^{152}$ where a law punishing certain acts was likely to be applied to a certain category of the population, to which the applicant belonged; ${ }^{153}$ and, lastly, where a measure had already been decided on but not yet executed and the enforcement of the measure would have exposed the persons concerned to a violation. ${ }^{154}$ In order for an applicant to claim to be a victim in such a situation, he must, however, produce reasonable and convincing evidence of the likelihood that a violation affecting him personally will occur; mere suspicion or conjecture is insufficient in this respect. ${ }^{155}$

146 Könkämä and 38 other Saami Villages v. Sweden (Appl. No. 27033/95), Decision of 25 November 1996, available at:

<http://cmiskp.echr.coe.int/tkp197/view.asp?action=html\&key=3389\&portal=hbkm\&source=external\&table $=$ 285953B33D3AF94893DC49EF6600CEBD49>.

147 But see e.g. Case of Open Door and Dublin Well Woman v. Ireland (Case No. 64/1991/316/387-388), Judgment of October 29, 1992, 246-A Eur. Ct. H. R. (ser. A), at para. 44.

148 See Case of Conf. des Syndicats Médicaux Francais et la Fédération Nationale des Infirmiers v. France (Appl. No. 10983/84), Decision of the Commission of 12 May 1986, available at

$<$ http://cmiskp.echr.coe.int/tkp197/view.asp?action=html\&key=8401\&portal=hbkm\&source=external\&table $=$ 285953B33D3AF94893DC49EF6600CEBD49>.

149 Christian Federation of Jehovah's Witnesses in France v. France (Appl. No. 53430/99) Decision of 06 November 2001, 2001-XI Eur. Ct. H.R. and Noël Narvii Tauira and 18 Others v. France, supra note 144.

150 See, e.g. Johnston and Others v. Ireland (Appl. No. 9697/82), Judgment of 18 December 1986, 112 Eur Ct. H.R. (ser. A), at para. 42 and Marckx v. Belgium (Appl. No. 6833/74), Judgment of 13 June 1979, 31 Eur Ct. H.R. (ser. A), at para. 27.

151 See for an overview Frowein/Peukert, supra note 142, § 25, at 24 and Zwart, supra note 102, at 51 et seq.

152 Klass and Others v. Germany (Appl. No. 5029/71), Judgment of 6 September 1978, 28 Eur Ct. H.R. (ser. A), at para. 33 .

153 See e.g. Dudgeon v. the United Kingdom (Appl. No. 7525/76), Judgment of 22 October 1981, 45 Eur. Ct. H.R. (ser. A) and Norris v. Ireland (Appl. No. 10581/83), Judgment of 29 September 1988, 142 Eur Ct. H.R. (ser. A), at para. 33.

154 Soering v. the United Kingdom (Appl. No. 14038/88), Judgment of 7 July 1989 (concerning extradition of aliens, resulting in a threat of a violation of Art. 3 ECHR) 161 Eur Ct. H.R. (ser. A) and Beldjoudi v. France (Appl. No. 12083/86), Judgment of 26 March 1992, 234 Eur Ct. H.R. (ser. A) where dismissal would have infringed the right to respect for family life.

See Noël Narvii Tauira and 18 Others v. France, supra note 144. 
Furthermore, the ECtHR has accepted that persons (especially close relatives) who are very close to the real victim within the meaning of Article 34 may exceptionally be regarded as a "victim" if, for practical purposes, it is impossible for the real victim to exercise his right of individual petition, for instance because she is deceased or suffering from some other incapacity. The ECtHR also admits petitions from close relatives on behalf of the victim, if the application was brought with the consent of the victim of the alleged breach and would avoid actio popularis applications. ${ }^{156}$ The ECtHR thus allows for nominal complainants.

Individual applicants may submit applications themselves, but legal representation is recommended, and even required if the Chamber so decides. ${ }^{157}$ The Council of Europe has set up a legal aid scheme for applicants who do not have sufficient means. ${ }^{158}$ The expenses of witnesses, experts and other persons whom the ECtHR hears at the request of an individual applicant may at the ECtHR's discretion be borne by the Council of Europe, ${ }^{159}$ in contrast to the cost allocation to the individual applicant under the American system. This alleviates substantially the monetary costs for applicants and thus augments the expected net benefit from a complaint.

All final judgments of the ECtHR are binding on the respondent States concerned. The responsibility for supervising the execution of judgments lies with the Committee of Ministers of the Council of Europe. ${ }^{160}$ The Committee of Ministers verifies whether States in respect of which a violation of the ECHR is found have taken adequate remedial measures to comply with the specific or general obligations arising out of the ECtHR's judgments. Nevertheless, the problem of systemic ${ }^{161}$ violations led to the consideration that the ECtHR should render precise measures in its judgments, ${ }^{162}$ and should identify systemic problems - recommendations the ECtHR followed

156 Case of Ilhan v. Turkey (Appl. No. 22277/93), Judgment of 27 June 2000, 2000-VIII Eur.Ct.H.R at para. 52 et seq. The dissenting opinion by Judge Gölcüklü at para 4. contests "the recognition given to the notion of "victim by proxy" accepted by the Court."

157 Rule 36 of the Rules of the Court of March 2005, available at: $<$ http://www.echr.coe.int/Eng/EDocs/RulesOfCourtMarch2005.pdf>.

158 See Art. 58 ECHR and Chapter X of the Rules of the Court as well as van Dijk/van Hoof, supra note 8, at 100.

159 Rule A5 (6); Annex to the Rules of the Court.

160 Art. 46 of Protocol No. 11, supra note 88. The implementation of the cases poses a problem especially in repeated violations cases, e.g. lengthy judicial procedures. See for an overview concerning the Court, Opinion No. 209/2002 on the Implementation of the Judgments of the European Court of Human Rights, supra note 20 .

161 The term „systemic“ is used by the Court, but in other judicial bodies the term „systematic“ is used. See for a detailed discussion Pia Carazo, "Schwere und systematische Menschenrechtsverletzungen: Praxis und Rechtsprechung der regionalen Menschenrechtsschutzsysteme”, doctoral thesis, Heidelberg forthcoming 2006, on file with the author.

162 Resolution (2004) 3 of the Committee of Ministers on Judgments Revealing an Underlying Systemic Problem. Adopted by the Committee of Ministers on 12 May 2004 at its 114th Session, available at: $<$ https://wcd.coe.int/ViewDoc.jsp?id=743257\&Lang=fr> recommending at para. I and II that the ECtHR should: "... as far as possible, [...] identify, in its judgments finding a violation of the Convention, what it considers to be an underlying systemic problem and the source of this problem, in particular when it is likely to give rise to numerous applications, so as to assist states in finding the appropriate solution and the Committee of Ministers in supervising the execution of judgments; to specially notify any judgment containing indications of the existence of a systemic problem and of the source of this problem not only to the state concerned and to the Committee of Ministers, but also to the Parliamentary Assembly, to the Secretary General of the Council of Europe and to the Council of Europe Commissioner for Human Rights, and to highlight such judgments in an appropriate manner in the database of the Court." 
immediately by even ordering in the operative part of the judgment appropriate legal measures to be adopted. ${ }^{163}$ Those kind of decisions, even though they still require the individual victim, amount to a functional equivalent of actio popularis concnering their legal consequence and amount to the provision of a collective good.

The ECtHR started to admit amicus curiae briefs in the beginning of the eighties by adopting new Rules of Procedure. ${ }^{164}$ From the case evidence as of 1994 it seems that more amicus curiae are filed in cases decided by the plenary court than by the Chambers, the reason for that being that the cases tend to be more important and the impact particularly broad. ${ }^{165}$ That seems to indicate a cost-benefit calculus by NGO briefers, which are presumably more interested in crucial, law-developing cases as those generate more publicity.

\section{b. American System of Human Rights}

The Inter-American system of human rights was created by the Organization of American States (OAS), ${ }^{166}$ and consists of several Conventions. The American Declaration of the Rights and Duties of Man $^{167}$ has a broad coverage of civil and political rights, as well as social, cultural and economic rights. Most important is the American Convention on Human Rights (ACHR), which contains in Chapter II only civil and political rights (Arts. 3-25). ${ }^{168}$

The Inter-American system of human rights protection centers around two monitoring bodies: the Inter-American Commission on Human Rights (IACHR) and the Inter-American Court of Human Rights (IAC). The IACHR was created in 1959 as an autonomous OAS organ, and later

163 As for the first recommendation, see Case of Assanidze v. Georgia, (Appl. No. 71503/01), Judgment of 8 April 2004, see at

<http://cmiskp.echr.coe.int/tkp197/view.asp?item=2\&portal=hbkm\&action=html\&highlight=Case\%20\%7C \%20of\%20\%7C\%20Assanidze\%20\%7C\%20v.\%20\%7C\%20Georgia\&sessionid=2435837\&skin=hudoc-en> and for the second recommendation, see Case of Broniowski v. Poland, supra note 143, where the ECtHR first identified a systemic problem and then ordered the first time in its history in the operative part of the judgment that the state had to take appropriate legal measures and administrative practices. As there were 167 other pending cases at the Court and about 80.000 similar cases in Poland, this was a decision trying to create a de facto erga omes obligation and by this means trying to avoid further cases coming to the Court. Here, the problem of ne ultra petita might be discussed, but in cases where national legislation is concerned, the same de facto erga omes effect always applied.

164 For the development including the relevant case law, see Shelton, supra note 8, at 630 et seqq.

165 Ibid., at 633 et seq. She finds that cases where amici were granted permission to intervene the Court found violations in $75 \%$ of the cases, whereas it found violations only in $50 \%$ of the cases where the amici were declined participation (at 637).

166 See Charter of the Organization of American States, Apr. 30, 1948, 2 U.S.T. 2394, 119 U.N.T.S. 3, T.I.A.S. 2361, as amended by the Protocol of Buenos Aires, Feb. 27, 1967, 21 U.S.T. 607, 721 U.N.T.S. 324. All 35 independent countries of the Americas have ratified the OAS Charter and belong to the Organization. Cuba remains a member, but its government has been excluded from participation in the OAS since 1962.

167 American Declaration of the Rights and Duties of Man, Res. XXX, OAS Int'l Conf. of Am. States, 9th Conf., OEA/ser. L/V/I.4 (1948), reprinted in Basic Documents Pertaining to Human Rights in the Inter-American System 17, OEA/ser. L.V/II.71, doc. 6 rev. 1 (1988).

168 This treaty protects twenty-six substantive rights, including, inter alia, the rights to life, humane treatment, personal liberty, a fair trial, privacy, and freedom of thought, expression, and religion. Chapter III, Art. 26, which contains economic, social and cultural rights, demands only progressive development. 
became a permanent part of the OAS through its inclusion as a charter organ. ${ }^{169}$ It has broad powers to promote and protect human rights in all member states of the OAS. As the ACHR states, "the main function of the Commission shall be to promote respect for and defense of human rights." ${ }^{170}$ The IACHR is empowered to report, as it wishes, on the general human rights situation in member states. It may also independently conduct on-site observations by factfinding missions in particular countries and for individual cases, with that government's consent. ${ }^{171}$ It has thereby a different function from the former European Commission.

The IACHR also examines petitions filed by individuals who claim the violation of a protected right and may recommend measures to be carried out by the state to remedy the violation. The IACHR cannot render legally binding judgments. ${ }^{172}$ Only if the country involved has accepted the IAC's jurisdiction, ${ }^{173}$ the IACHR may submit the case to the IAC for a binding decision. It then appears before the IAC in the litigation of the cases. Whereas the IAC may only apply the ACHR, the IACHR ${ }^{174}$ may apply also other Conventions, i.a. the Additional Protocol in the Area of Economic, Social and Cultural Rights. But even this protocol only admits the justiciability of two rights, i.e. trade union rights (Art. 8) and the right to education (Art. 13). ${ }^{175}$ Thus, a whole array of rights, including rights with a more collective character is covered by the Inter-

169 The IACHR was created already by the Charter of the OAS in 1959 and entered into force in 1960. See Protocol of Amendment to Charter of the Organization of American States, Feb. 27, 1967, 21 U.S.T. 607, T.I.A.S. No. 6847, 721 U.N.T.S. 324, Art. 51.

170 Art. 41 ACHR.

171 The IACHR carries out those on-site visits to countries to engage in more in-depth analysis of the general situation or to investigate a specific situation. These visits usually result in the preparation of a report regarding the human rights situation observed, which is published and presented to the Permanent Council and General Assembly of the OAS. The IACHRs' functions regarding individual petitions have increased in importance as its on-site visits and country reports have faded, see Christina Cerna, "The Inter-American System for the Protection of Human Rights”, Florida Journal of International Law 16 (2004), 195-212, at 199.

172 But see for the practice of recognizing the obligatory character of the IACHRs' recommendations, Christina Cerna, "The Inter-American Commission on Human Rights: Its Organization and Examination of Petitions and Communications”, in: David J. Harris/Stephen Livingstone (eds.), The Inter-American System of Human Rights, 1998, Oxford, 65-114, at 104 et seq. Furthermore, the IACHR changed rule 44 of its Rules of Procedure, which provides that if the state has not complied with the Inter-American Commission's recommendations as set forth in the merits report on the case, the case shall be sent to the Inter-American Court of Human Rights, unless four members of the IACHR take a reasoned decision that it should not be sent.

173 Art. 62 (3) ACHR. As of 1 January 200321 State Parties to the Convention had accepted the compulsory jurisdiction of the Court as binding ipso facto. Acceptance may also occur on an ad hoc basis for a special case. The Court has powers to issue decisions of both an advisory nature as well as in contentious cases.

174 The procedures for individual complaints from the OAS Charter System and the ACHR systems are found in different sources. In Case of the OAS Charter system, the complaints procedure is provided by regulation 5154 of the IACHR's Regulations, whereas the complaint procedure under the ACHR are contained in ACHR. In the OAS system, the IACHR may not transfer the cases to the IAC and is thus the final decision maker. See for an example of this two-tiers system for the Inter-American Convention on the Prevention, Punishment and Eradication of Violence Against Women Anthony P. Ewing, "Establishing State Responsibility for Private Acts of Violence Against Women under the American Convention on Human Rights”, Columbia Human Rights Law Review 26 (1995), 751-800, 795.

175 Art. 19 of the Additional Protocol to the American Convention on Human Rights in the Area of Economic, Social, and Cultural Rights "Protocol of San Salvador," Inter-Am. C.H.R. 67, OEA/ser. L./V./II.82, doc. 6 rev.1 (1992). 
American system for those cases which may be submitted to the IACHR, ${ }^{176}$ as opposed to cases submitted to the IAC, which only deals with the ACHR.

There is no individual complaint possibility directly to the IAC, which significantly restricts access. ${ }^{177}$ Only States Parties and the IACHR have the right to submit a case to the IAC. ${ }^{178}$ Nevertheless, the alleged victims, their next of kin or their duly accredited representatives may submit their pleadings, motions and evidence autonomously throughout the proceedings, that is, they have been granted locus standi in judicio, i.e. the entitlement to participate directly in all stages of the procedure before the IACHR. ${ }^{179}$ There is no requirement of legal representation and thus the costs are low in this respect. But the costs of evidence are borne by the parties, including the costs for the calling of witnesses. ${ }^{180}$ If the IAC finds that there has been a violation of a right or freedom protected by the ACHR, the IAC rules that the injured party be ensured the enjoyment of the right or freedom that was violated. It may also rule, if appropriate, that the consequences of the measure or situation that constituted the breach of such right or freedom be remedied and that fair compensation be paid to the injured party. ${ }^{181}$ The decisions of the Court are very precise concerning remedies and usually go further than just stating a violation and further than just or-

176 Art. 23 IACHR 2003 Rules of Procedure, approved by the IACHR at its $109^{\circ}$ special session held from December 4 to 8, 2000 and amended at its 116th regular period of sessions, held from October 7 to 25, 2002, spells out the other treaties under which a petition may be brought: the American Declaration of the Rights and Duties of Man, which is very broad in its coverage and includes economic, social and cultural rights, the Additional Protocol in the Area of Economic, Social and Cultural Rights, the Protocol to Abolish the Death Penalty, the Inter-American Convention to Prevent and Punish Torture, the Inter-American Convention on Forced Disappearance of Persons, and the Inter-American Convention on the Prevention, Punishment and Eradication of Violence Against Women, in accordance with their respective provisions, the Statute of the Commission, and the IACHR 2003 Rules of Procedure.

See for an overview of the Treaties: <www.corteidh.or.cr/afines_ing/american.html>.

177 This is frequently criticized, see for an overview with further references Pasqualucci, supra note 52, at 22 et seqq. Nevertheless, the Court and the IACHR moved toward giving the petitioner greater autonomy. The IACHR ,shall“ now refer a case to the Court, "unless there is a reasoned decision by an absolute majority of the members of the Commission to the contrary“, Art. 44 (1) IACHR 2003 Rules of Procedure. Art. 69 (2) IACHR 2003 Rules of Procedure states that if the petitioner so requests, the IACHR shall include him or her as a delegate.

178 Art. 61 (1) ACHR. In order for the IAC to hear a case, it is necessary that the procedures set forth in Articles 48 and 50 shall have been completed (Art. 61 (2) ACHR). Those articles cover the procedures of the IACHR.

179 The landmark decision on the issue of the complainants' participation came in I/A Court H.R. Case of El Amparo v. Venezuela. Judgment of January 18, 1995 (Series C, No. 19). By now the participation is included in Art. 23 Rules of Procedure of the Inter-American Court of Human Rights, approved by the Court during its XLIX Ordinary Period of Sessions, held from November 16 to 25, 2000, and partially reformed by the Court during its LXI Ordinary Period of Sessions, held from November 20 to December 4, 2003. When there are several alleged victims, next of kin or duly accredited representatives, they shall designate a common intervener who shall be the only person authorized to present pleadings. See for an appraisal of this new rule, Cerna, supra note 171, at 204 et seq.

180 Art. 46 (2) Rules of Procedure of the Court.

181 Article 63(1) ACHR reads as follows: „If the Court finds that there has been a violation of a right or freedom protected by this Convention, the Court shall rule that the injured party by insured the enjoyment of his right or freedom that was violated. It shall also rule, if appropriate, that the consequences of the measure or situation that constituted the breach of such right or freedom be remedied and that fair compensation be paid to the injured party.“ 
dering pecuniary compensation. ${ }^{182}$ The decisions are published ${ }^{183}$ and the Court supervises itself the compliance with its decisions by documenting the non-compliance in its reports. ${ }^{184}$

As petitions need to go trough the admissibility procedures of the IACHR, which thus acts as the gate keeper, the following will mainly focus on the standing provisions of the IACHR. The IACHR receives, analyzes and investigates individual petitions that allege human rights violations, ${ }^{185}$ and declares petitions inadmissible only if there is no prima facie case for a violation. ${ }^{186}$ The IACHR may also initiate the processing of a petition motu proprio, which, in its view, prima facie meets the necessary requirements. ${ }^{187}$ This arrangement shows the wide ambit of tasks and the very active role the IACHR is supposed to play in the Inter-American context.

Any person or group of persons, or any nongovernmental entity legally recognized in one or more member states of the Organization, may lodge petitions with the IACHR containing denunciations or complaints of violation of a right recognized in the ACHR, the American Declaration or other pertinent instrument in accordance with their respective provisions and the IACHR's Statute and Rules. ${ }^{188}$ It allows groups of individuals to bring a case. Corporations and legal entities are excluded as victims because of the wording "person", which is understood to mean "human being". ${ }^{189}$ The wording of Art. 44 ACHR dispenses with the victim requirement found in other human rights treaties, although that does not imply the victim requirement is dispensed with altogether, rather it allows for nominal complainants. The IACHR has therefore understood this requirement to be broad; in principle anyone may file a petition, even without the authorization of the actual victim. ${ }^{190}$ Petitions may also be lodged by third parties with no direct stake in

182 See e.g. reward of damages, including immaterial damages, for disappearances in I/A Court H.R. Case of Velásquez-Rodríguez v. Honduras. Judgment of July 29, 1988 (Series C, No. 4) and I/A Court H.R. Case of Godínez-Cruz v. Honduras. Judgment of January 20, 1989 (Series C, No. 5). See also I/A Court H.R. Case of Aloeboetoe et al. v. Suriname. Judgment of September 10, 1993 (Series C, No. 15), where the court not only ordered material and immaterial damages for the whole tribe (because seven of its members were murdered), but also requested the establishment of two trust funds and a foundation as well as ordered to reopen the school, where the tribe is located.

183 Art. 30 Rules of Procedure of the Court.

184 Arts. 67 and 68 (1) ACHR. The monitoring reports are published on the website and are very detailed. See $<$ www.corteidh.or.cr/cumpli_ing/index.html $>$. Generally, states partly comply with the Court's judgments and orders of provisional measures. In most cases, the state is prepared to pay the pecuniary reparations ordered by the Inter-American Court, but only in the rarest case is it willing to investigate, try and punish the perpetrators, see Cerna, supra note 171, at 203 et seq.

185 Pursuant to Arts. 44 to 51 of the ACHR, Arts. 19 and 20 of the IACHR's Statute, and Arts. 22 to 50 of the IACHR 2003 Rules of Procedure.

186 See Art. 46 and 47 ACHR for admissibility conditions.

187 Art. 24 IACHR 2003 Rules of Procedure. The Court cited this provision, in I/A Court H.R. Case of Blake v. Guatemala, Judgment of January 24, 1998 (Series C, No. 36), at para. 85, where the Court stated that it "was surprised that the Commission did not use its authority to include Mr. Griffith Davis (who also disappeared, A.v.A.) as an alleged victim in the application.“

188 Art. 44 ACHR and Art. 23 IACHR 2003 Rules of Procedure.

189 Art. 1 (2) ACHR, see also Cerna, at supra note 172. Nevertheless, shareholders as natural persons or owners of businesses may file complaints, also on behalf of the legal entity. See with an interesting reasoning I/A Court H.R. Case of Cantos v. Argentina. Preliminary Objections. Judgment of September 7, 2001 (Series C, No. 85), at para. 22-29.

190 Pasqualucci, supra note 52, at 100, Diego Rodriguez Pinzon, "The "Victim" Requirement, The Fourth Instance Formula and the Notion of "Person" in the Individual Complaint Procedure of the Inter-American Human Rights System”, ILSA Journal of International and Comparative Law 7 (2001), 369-383, at 373 et seq. and Carazo, supra note 161, Chapter II. C. II. 3. a). 
the conflict on behalf of the victims. ${ }^{191}$ Thus, the system also allows for NGOs and individuals to bring an altruistic complaint. ${ }^{192}$ In sum: anybody, that is, individuals, groups or NGOs may bring a complaint, but the victim requirement is upheld, that is, (potential) victims must at least be identifiable. ${ }^{193}$ They should be named "if possible". ${ }^{194}$

Even though the text of Art. 44 ACHR allows only for complaints brought by NGOs legally recognized in one or more member states of the Organization, the IAC admitted petitions from NGOs which were not recognized in the respective country. ${ }^{195}$ This jurisdiction dismisses the gate-keeping possibility for states, which may hinder complaints by a restrictive recognition praxis for NGOs.

Concerning groups, the standing requirement is also broad. Not only may the IACHR and the IAC, at any stage of the proceedings, order the joinder of interrelated cases, when there is identity of the parties, subject-matter and ruling law. ${ }^{196}$ As set out above, this only leads to a small cost reduction, as then every complainant is still filing an individual petition. But the IAC also allows for groups as a whole to file complaints, alleging a violation of group rights. ${ }^{197}$ Here, not all of the victims need to be named by previous identification. This is especially useful for indigenous people.

In spite of the very broad standing requirement, IACHR and IAC do not hear cases in abstracto. Therefore, the IACHR admits only petitions which allege a concrete violation of specific human rights. This means in principle that an actio popularis which is filed in the general interest to

191 Art. 44 ACHR and Art. 23 IACHR 2003 Rules of Procedure do not contain an explicit victim requirement. See I/A Court H.R. Case of the Constitutional Court v. Peru. Judgment of September 24, 1999 (Series C, No. 55), at para. 3, where 27 Peruvian Congressional Representatives filed a petition on behalf of 3 dismissed Constitutional Judges of Peru.

192 I/A Court H.R. Bustios-Rojas Case v. Peru, (Provisional Measures), Order of the President of the InterAmerican Court of Human Rights of June 5, 1990. See also Pasqualucci, supra note 52, at 101, who views this system especially useful in the American context, where poverty, lack of education and lack of legal assistance might otherwise hinder access to the IACHR.

193 See I/A Court H.R. Case of Haitians and Haitian-origin Dominicans v. Dominican Republic, Order of the Inter-American Court of Human Rights of August 18, 2000, at para. 8 (considerations). See also Dinah Shelton, "The Legal Status of the Detainees at Guantanamo Bay. Innovative Elements in the Decision of the Inter-American Commission on Human Rights of 12 March 2002”, Human Rights Law Journal 23 (2002), 13-14 and with a different interpretation of the decision Carazo, supra note 161, Chapter II, C.II.3.a) i).

194 See Art. 28 e) IAHCR 2003 Rules of Proecedure.

195 I/A Court H.R. Case of Castillo-Petruzzi v. Peru. Preliminary Objections. Judgment of September 4, 1998 (Series C No. 41), at para. 77.

196 Art. 28 Rules of Procedure of the Court. The Court may also order that the written or oral proceedings of several cases, including the introduction of witnesses, be carried out jointly.

197 This practice started already in the seventies. See for further cases Carazo, supra note 161, Chapter II. C. II. 3. a). IACHR Case No. 1690 v. Columbia, at 112. Also IACHR Case. No. 1802 v. Paraguay, May 27, 1977, at 34 et seq. and IACHR Case No. 11.071, Cherokee Nation v. US, March 12, 1997, which was declared inadmissible only due to the non-exhaustion of domestic remedies. More recently there was the I/A Court H.R. Case of The Mayagna (Sumo) Awas Tingni Community v. Nicaragua. Preliminary Objections. Judgment of February 1, 2000 (Series C, No. 66), where a petition was lodged by Jaime Castillo Felipe, principal leader of the Community, in his own name and on behalf of the Community (about 630 people). See for that decision S. James Anaya / Claudio Grossman, “The Case of Awas Tingni v. Nicaragua: A New Step in the International Law of Indigenous People”, Arizona Journal of International and Comparative Law 19 (2002), 1-15. 
have an alleged illegal situation or law scrutinized, is not permitted. ${ }^{198}$ Nevertheless, cases are considered, where a law per se amounts to a potential violation, that is, a potential victim may have the rights to file a complaint, similarly to the ECtHR jurisdiction. ${ }^{199}$ Especially if a law affects a considerable part of the population, e.g. because it is discriminatory against a certain class, and the whole class is potentially affected, this would amount to a violation of all members of the class. ${ }^{200}$ Thus, under the Inter-American system, complaints in abstracto are inadmissible, but it allows for collective complaints by NGOs and it allows for group complaints. This alleviates strongly the incentive problems identified above.

Already in the very beginning the IAC took the step, which the ECtHR just took in 2004, of deciding in its operative part of the decision on general measures the state has to take, even when dealing with a singular case, ${ }^{201}$ perhaps because of higher occurrence of systemic problems, or maybe because its mandate is broader. It did not stop short of ordering the necessary repeal of a law by stating that the respondent state, in order to fulfill its international obligations, has to adopt internal legal measures. ${ }^{202}$ It thereby extended the collective good character of precedent by producing a collective good concerning legal or administrative measures to be taken.

The petitioner may, but does not need to, designate an attorney or other person to represent her before the IACHR. ${ }^{203}$ There is no legal aid provided for and legal costs are not explicitly recoverable by a winning petitioner but may be included in the award. ${ }^{204}$ Many alleged victims are too poor to hire lawyers and would need to do so at least in the domestic legal system - which they need to go through due to the requirement to exhaust domestic remedies. The IAC has seen this problem and therefore dispensed with the domestic remedies requirement in exceptional cases,

198 E.g. the IACHR declared a case inadmissible in which the petitioners alleged discriminatory application of the death penalty in detriment of black persons in the US. IACHR Case $7465 \mathrm{v}$. US, Decision of October 4, 1984. See for further cases Carazo, supra note 161, Chapter II. C. II. 3. a).

199 I/A Court H.R. Case of Hilaire, Constantine and Benjamin et al. v. Trinidad and Tobago, Judgment of June 21, 2002 (Series C, No. 94), at para. 116 at seq. and I/A Court H.R. Case of Suárez-Rosero v. Ecuador, Judgment of November 12, 1997 (Series C, No. 35), at para. 98.

200 I/A Court H.R., International Responsibility for the Promulgation and Enforcement of Laws in Violation of the Convention. Advisory Opinion OC-14/94 of December 9, 1994, (Series A, No. 14), at para. 41 et seqq. See also Pasqualucci, supra note 52, at 105.

201 See e.g. I/A Court H.R. Case of Bámaca-Velásquez v. Guatemala. Reparations (Art. 63(1) American Convention on Human Rights). Judgment of February 22, 2002 (Series C, No. 91), at para. 106 (4).

202 Whereas in I/A Court H.R. Case of Loayza-Tamayo v. Peru. Compliance with Judgment. Order of November 17, 1999 (Series C, No. 60), at para. 12 (d), the court was more cautious in I/A Court H.R. Case of Barrios Altos v. Peru. Interpretation of the Judgment on the Merits. Judgment of September 3, 2001 (Series C, No. 83), at para. VI, 17 the court stated that there was a general obligation of the State to adopt measures to suppress laws and practices of any kind that imply a violation of the guarantees established in the Convention, and also to adopt of laws and the implementation of practices leading to the effective observance of the relevant guarantees. It further stated in its operative part at para. 2 that the judgment had generic effects.

203 Art. 23 IACHR 2003 Rules of Procedure.

204 Art. 65 (1) (h) of the Rules of Procedure of the Court states that the judgment shall contain: "the decision, if any, on reparations and costs.“ 
where the alleged victims are too poor or too frightened. ${ }^{205}$ The IAC also has the most extensive practice of admitting amicus curiae. ${ }^{206}$

\section{c. African Charter on Human and Peoples' Rights}

In 1981, the Assembly of Heads of State and Government of the Organization of African Unity (OAU) adopted the African Charter on Human and Peoples' Rights (African Charter or "Banjul Charter"). ${ }^{207}$ The Charter contains provisions for civil and political rights (Arts. 3-14) and economic, social and cultural rights (Arts. 15-18). It however blazes new ground by including rights of peoples as collective rights (Arts. 19-24) and duties (Arts. 25-29). ${ }^{208}$

The only mechanism created under the Charter to supervise States Parties' compliance was the African Commission on Human and Peoples’ Rights (African Commission). ${ }^{209}$ Its four areas of mandate are: promotional activities, protective activities (including individual complaints), the examination of State Party reports, and the interpretation of the African Charter (Art. 45). It has the capacity to receive inter-state complaints (Art. 47 et seq.) and complaints by other parties (Art. 55 et seq.). It may also invite any organization or persons capable of enlightening it, e.g. NGOs, to participate in its deliberations without voting rights. ${ }^{210}$ While the African Commission has an elaborate promotional mandate under the African Charter, it does not possess sufficient protective powers. Despite some positive development in the African Commission's individual complaint mechanism, the decisions it renders are non-binding, and attract little, if any, attention from governments of Member States. ${ }^{211}$ The reports become final only once they are contained in the African Commissions Annual reports and are approved by the AU Assembly, a political body. Furthermore, the findings are not published before that, ${ }^{212}$ which diminishes greatly the collective good character of precedents. There is no instituted system of follow-up concerning the implementation and compliance of the findings. ${ }^{213}$

205 I/A Court H.R., Exceptions to the Exhaustion of Domestic Remedies. Advisory Opinion OC-11/90 of August 10, 1990 (Series A, No. 11), at para. 3. The Court also makes an exception where an individual is unable to obtain the necessary legal representation due to a general fear in the legal community of a given country. The Commission explains that, according to what some complainants have alleged, this situation has occurred where an atmosphere of fear prevails and lawyers do not accept cases which they believe could place their own lives and those of their families in jeopardy (at para. 32 and 35).

206 Thomas Buergenthal, “The Advisory Practice of the Inter-American Human Rights Court”, American Journal of International Law 79 (1985), 1-27, at 15.

207 Of June 21, 1986, OAU Doc. CAB/LEG/67/3 rev. 5, 21 I.L.M. 58 (entered into force Oct. 21, 1986).

208 Unlike other international or regional human rights treaties, the Charter does not allow states to derogate from their treaty obligations even during states of emergency. See e.g. Communication 74/92, Commission Nationale de Droits de l' Homme et des Libertes v. Chad.

209 Art. 30 of the African Charter provides for the establishment of the Commission.

210 Rule 72 and 73 of the Rules of Procedure of the African Commission on Human and Peoples' Rights, OAU Doc. ACHPR/RP/XIX (1988) (amended June 10, 1995) (hereinafter Rules of Procedure), available at $<$ http://www.hrni.org/files/instruments/HRNi_EN_926.html>. NGOs may be granted observer status by the Commission and may appoint authorized observers to participate in the public sessions of the Commission and of its subsidiary bodies.

211 See Nsongurua J. Udombana, "An African Human Rights Court and An African Union Court: A Needful Duality or a Needless Duplication?”, Brooklyn Journal of International Law 28 (2003), 811-870, 821.

212 Art. 59 (1) African Charter.

213 See for more details Viljoen, supra note 138. 
The bright side of the system can be found in the broad access to the African Commission. The vaguely formulated Art. 55 of the African Charter, which also provides for individual complaints, was more clearly outlined in Chapter XVII of the Rules of Procedure of the African Commission, but still leaves huge interpretative leeway to the African Commission. There is no requisite for a victim requirement, so the African Commissions' decisions are decisive to determine the ius standi under the African Charter. The African Commission allows individual and group complaints, but also altruistic NGO communications, either on behalf of named victims or NGO complaints alleging human rights violations without specifying victims' names. ${ }^{214}$ The African Commission thus dispensed with the requirement of naming the individual victims, thereby allowing for a communication of NGOs alleging human rights violations without specifying victims. ${ }^{215}$ The African Commission held that Art. 56(1) of the Banjul Charter requires only that communications indicate their authors, not the names of all the victims, as the more massive the violation, the greater the likelihood that the victims will be numerous. This permits communications to be brought by a few individuals on behalf of many. It is - in the African Commission's view - also a rational response to the great difficulties that victims themselves may encounter in bringing communications, in just such circumstances of economic hardship and political repression as were alleged in the Communication at hand. ${ }^{216}$ Most of the communications received by the African Commission have been submitted by NGOs, both African and foreign on behalf of (a group of) individuals. Thus in practice, the African Commission receives communications from any person or organization. ${ }^{217}$

Therefore it seems safe to say that the African Commission allows in principle for actio popularis, ${ }^{218}$ but one needs to bear in mind that, because of the requirement for NGOs to be registered with the AU in order to have standing, the actio popularis in its "classical" sense is restricted and a filter is provided. ${ }^{219}$ A true actio popularis would allow virtually everybody to file a communication. In practice though, the African Commission understands this broad standing requirements as an actio popularis, which it described in the famous Ogoni case as useful and as "wisely allowed under the African Charter.,220

214 See Communications 25/89, 47/90, 56/91 and 100/93 (World Organisation Against Torture et al./Zaire) and Communication 155/96 (Social and Economic Rights Action Center/Center for Economic and Social Rights v. Nigeria), where the commission held, at para. 42, that where the author of a communication is a nongovernmental organization, and the situation is one of serious or massive violations, it may be simply impossible for the author to collect the name of each individual victim.

215 Ibid. at para. 42 and Communications 25/89, 47/90, 56/91 and 100/93 World Organisation Against Torture et al. v. Zaire, where it held that if the situation is one of serious or massive violations, it may be simply impossible for the author to collect the name of each individual victim.

216 Communication 155/96 (Social and Economic Rights Action Center/Center for Economic and Social Rights v. Nigeria), at para. 40 et seq.

217 Essien, supra note 138, at 106.

218 Bernard H. Oxman/Dinah Shelton, "Decision regarding Communication 155/96 (Social and Economic Rights Action Center/Center for Economic and Social Rights v. Nigeria)”, American Journal of International Law 96 (2002), 937-942, at 937.

219 Some 300 NGOs, including international and non-African NGOs, had been granted observer status with the African Commission. See Directory of NGOs with Observer Status (listing dates on which observer status granted), http://www.achpr.org/english/_info/directory_ngo_en.html (last visited May 16, 2005).

220 Communication 155/96 (Social and Economic Rights Action Center/Center for Economic and Social Rights v. Nigeria), at para. 51 . 
In 1998, the Assembly of Heads of State and Government of the now-defunct Organization of African Unity ("OAU“), replaced in 2002 by the African Union (”AU“) adopted a Protocol to the African Charter, which establishes a Court to complement the protective mandate of the African Commission and defines the organization, jurisdiction, and functioning of the Court. ${ }^{221}$ It came into force only in January 2004 and the Court has not yet been set up, but the system concerning the admissibility condition of ius standi will already be included here. Both the African Commission and the Court have the jurisdiction to apply the provisions of the African Charter and any other relevant human rights instruments ratified by the States concerned as relevant law. The Protocol thus provides that complaints may be brought on the basis of any instrument, including international human rights treaties, which have been ratified by the State Party in question. ${ }^{222}$

The African Commission and the Court will form a two-tier system, similar to the one under the ACHR. The Court proceedings will be public and the decision will be published, which leads to a greater collective good character of the decisions compared to the old system due to the immediate publicity of precedents developing IHRL. ${ }^{223}$ If the Court finds that there has been violation of a human or peoples' rights, it shall make appropriate orders to remedy the violation, including the payment of fair compensation or reparation. ${ }^{224}$ The Court will render legally binding decisions. ${ }^{225}$ The States Parties are supposed to comply with the judgment within the time stipulated by the Court and to guarantee its execution. ${ }^{226}$ Non-compliance will be reported annually by the Court to the Assembly. ${ }^{227}$ The Executive Council (former Council of Ministers) of the AU will assist in monitoring the implementation of the court's decisions. ${ }^{228}$

Under Art. 5 of the Protocol the Court may accept communications from the following parties: The African Commission, the State Party which had lodged a complaint to the Commission, the State Party against which the complaint has been lodged at the Commission, the State Party whose citizen is a victim of human rights violation, and African Intergovernmental Organizations. When a State Party has an interest in a case, it may submit a request to the Court to be permitted to join. It must be borne in mind that the Protocol only provides for optional jurisdiction with respect to individuals and NGOs. Additionally, the Court may entitle relevant NGOs with observer status before the African Commission, and individuals to institute cases directly before it, if the State Party made a declaration accepting the competence of the Court to receive such cases. ${ }^{229}$ Nevertheless, even if a respective declaration for individual complaints to the

221 See Protocol to the African Charter on Human and Peoples' Rights on the Establishment of an African Court on Human and Peoples' Rights, OAU Doc. OAU/LEG/MIN/AFCHPR/PROT.1 rev.2 (1997), entered into force January 25, 2004 (hereinafter: Protocol).

222 For the Commission: Art. 60 and 61 of the African Charter and for the Court: Art. 3 and 7 of the Protocol.

223 Art. 10 (1) of the Protocol.

224 Art. 27 (1) of the Protocol.

225 Art. 28 (2) and Art. 30 of the Protocol and Viljoen, supra note 138, at 13 as well as Udombana, supra note 211, at 834.

226 Art. 30 of the Protocol.

227 Art. 31 of the Protocol.

228 Art. 29(2) of the Protocol.

229 Art. 5 (3) and Art. 34 (6) of the Protocol: „At the time of the ratification of this Protocol or any time thereafter, the State shall make a declaration accepting the competence of the Court to receive cases under article 5 (3) of this Protocol. The Court shall not receive any petition under article 5 (3) involving a State 
Court has not been made by the states, the way through the African Commission is in any case still open - there will be thus a "Commission-mediated direct access". ${ }^{230}$ Under its rules of evidence, the Court is free to admit NGOs as amici curiae. ${ }^{231}$

Although the African system provides not only for individual and group complaints but also for actio popularis and altruistic NGO complaints and thus has the most broad definition of standing of all others IHR treaties, it received considerably less communications than its European and American predecessors. ${ }^{232}$ Possible reasons may not only lie in the anticipated non-compliance of the respondent state but also in the absence of provisions for legal aid or for the awarding of costs in either the Charter or the Commission's Rules of Procedure. Furthermore, poverty, lack of education and lack of legal assistance might hinder access to the Commission. It remains to be seen if the use of complaints mechanisms will rise due to the installation of the Court.

\section{Evaluation of International Human Rights Provisions of lus Standi from a Rational-Choice Perspective}

An evaluation of the different systems according to their ius standi provisions and the substantive rights covered necessarily needs to be superficial. Nevertheless, some advantages and disadvantages of the presented procedural provisions are discussed in the following.

With the exception of the Inter-American and the African system, all human rights treaties provide only for the possibility of an individual complaint or joinders, i.e. the individual right holder, whose right is deemed to be infringed may bring a complaint (possibly together with others). This might make sense for rights which only protect individual interests, but is certainly insufficient for group or minority rights like, e.g., Art. 27 CCPR. But cases involving large collective good aspects, e.g. rights which may only be collectively exercised or rights concerning environmental matters, e.g. noise, pollution or clean water, typically involve large-scale violations. In most parts of the world, including the member states of the Council of Europe, the problem of systemic violations is also pervasive. For all those cases, collective complaints are an appropriate means for several reasons. As mentioned before, judicial economy demands a bundling of similar cases. Furthermore, collective complaints may call for a heightened scrutiny on the part of the monitoring bodies and the public, including NGOs, and therefore foster compliance with the judgments or views.

The UN-treaty based system is the strictest system concerning ius standi admissibility for individual complaint mechanisms, in spite of the huge geographical area the treaties cover and in

Party which has not made such a declaration." As of 30 August 2004, from the 19 countries, which ratified the Protocol, only Burkina Faso made a declaration under Art. 34 (6).

230 Viljoen, supra note 138, at 25 with several scenarios on how the interplay between the Commission and the Court could function.

231 Art. 26 (2). See for this possibility also Abdelsalam A. Mohamed, "Individual and NGO Participation in Human Rights Litigation before the African Court of Human and Peoples' Rights: Lessons from the European and Inter-American Courts of Human Rights”, Journal of African Law 43 (1999), 201-213, at 204.

See supra note 138 . 
spite of the often bad socio-economic and educational circumstances which may hinder individual complaints. It is therefore unsurprising that the system is thoroughly underused and that the communications brought under the UN-Treaty based mechanism, which allow only for individual complaints or joinders mostly originate from developed countries. ${ }^{233}$ Here, NGOs are usually better organized and active in human rights issues. They often bring the cases as representatives for individuals. ${ }^{234}$ Whereas one could assume that the issuing of non-binding decisions is counterbalanced by a broadening of standing, as is the case with the African Commission and the IACHR, this does not apply for the UN-treaty based system. Furthermore, there are no legal aid provisions, as opposed to the ECtHR. Although neither the African nor the Inter-American systems have legal aid provisions, they provide at least for altruistic NGO complaints, which shift the all the monetary and non-monetary costs of complaints from the victims to the NGOs. Altruistic NGO complaints are also especially suited to overcome the problem of judicial access. Thus, under the UN-treaty based system, substantial barriers exist for human rights complainants pursuing justice independently. ${ }^{235}$ That problem might be mitigated by NGOs or lawyers acting as representatives pro bono, but it does not solve the problem in all constellations.

All international human rights treaties or the respective Rules of Procedure allow for joinders. While joinders allow for certain claims to be brought in a single proceeding, they still require each victim to file an individual petition and leave the individual in principle alone with bearing the costs for her representative, all other costs and all risks. Joinders may alleviate the workload of the court, but do not foster the incentive to bring a complaint, especially if the gathering of potential other victims is difficult for the initiating complainant. That raises the costs in the first place, but may alleviate the costs afterwards. Joinders are therefore nothing but an intermediate step for solving the problem. Nevertheless, it should be noted that all regional treaties as well as the CERD and the CEDAW also explicitly allow for joinders, which makes sense, as discriminatory cases usually afflict a whole group.

Some treaty provisions provide for rights of minorities and "peoples' rights", for example Art. 27 CCPR (even if the right is understood to be an individual right by the HRC) and the African Charter. Nevertheless, the FOP to the CCPR states in Art. 1 explicitly that only individuals (also in the form of joinders) may bring a complaint before the HRC. Group complaints are not permitted at all before the UN Committees, which makes it more difficult to bring complaints concerning rights with a collective aspect, e.g. Art. 27 CPPR. Yet, a community of human rights victims may find proceeding as a group desirable because this kind of representative justice may sometimes provide the only possible way of rendering justice to victims of a particular policy, especially if group and minority rights are at stake. Currently, individuals seeking justice and some form of redress for their injuries mostly must file individual petitions - a provision which is not adequate for rights which may only be exercised collectively.

233 In the case of CERD, all the cases were directed against developed countries (except from Australia and Serbia and Montenegro, all countries are members of the EU) and most were communicated by non-citizens. In the case of the HRC, about $45 \%$ of the communications are from developed countries.

234 Neumayer, supra note 6, finds that countries with better NGO organization have better human rights records.

235 See Aceves, supra note 47, at 354. 
With the exception of the African system and the Inter-American system, altruistic complaints brought by NGOs are not permissible. The African Commission, admitting altruistic NGO complaints, was well aware of the circumstances in Africa, which inhibit the filing of complaints and therefore opened the gate for NGOs. Also, it considered this step necessary because of the group and peoples' rights included in the African Charter. Due to the collective good context inherent in those rights, there is a particularly strong disincentive to claim those rights before a judicial body. This reasoning would thus apply to all those treaties which provide for minority and group rights. But also infringements of individual rights with a possibly huge collective aspect, such as racial or gender discrimination, are suited for NGO complaints. Furthermore, if the victims do not have to be named, altruistic NGO complaints minimize non-monetary costs for victims such as the risk of repression by state actors. NGOs have the advantage of being "professional" in the field, thus fighting with more equal swords. In very poor countries, they may also be the only possibility of raising awareness and bringing a claim - class actions need a minimal access to the legal sphere, whereas in NGO cases, the victims only need to be identifiable or give their consent. NGO complaints may also bring along greater publicity and therefore foster compliance of the respondent state with the decision. Of course, this situation is not unique to the InterAmerican or African context. Rather, it applies in most regions of the world and thus, if effective enforcement of the human rights treaties is desired, NGO complaints should be introduced. Empirical research supports that result: human rights treaty ratification is more beneficial if there is a strong civil society, that is, the more citizens participate in international NGOs. ${ }^{236}$

With the exception of the African system, actio popularis is not admissible. But deplorable socio-economic and political conditions, low levels of literacy, unavailability of access to media, and arbitrary denial of justice which might inhibit individual access to complaint mechanisms are not unique to Africa. ${ }^{237}$ Furthermore, victims often lack the resources necessary to pursue a claim or lack access to lawyers or to courts able to hear their claims. Human rights complainants may also lack basic knowledge of their legal rights under international law. ${ }^{238}$ If widespread violations occur, few people would bring a complaint for rational reasons, with the exception of NGOs, which in the Inter-American cases still have to name the victims or at least have to make the victims identifiable. That might also constitute a huge hurdle. Consequently the African Commission has dispensed with the naming requirement. An actio popularis, also for NGOs, might be the only appropriate legal solution for those cases. Abuse of actio popularis is not to be expected, as argued above, and furthermore can be dealt with through other legal means, such as abuse provisions, existent in all treaties.

None of the treaties allow for class actions. The class action mechanism also has the potential to give force to grievances about government practices and policies that violate individual human rights on a collective scale. Adopting an expansive conception of the causes of the harm alleged by members of the class facilitates the discovery and disclosure of a pattern of wrongdoing, per-

236 Neumayer, supra note 6.

237 See Jo M. Pasqualucci, “The Inter-American Human Rights System: Establishing Precedents and Procedure in Human Rights Law”, University of Miami Inter-American Law Review 26 (1995), 297-361, at 314 et seq. 
haps not readily apparent from singular or scattered cases. This allows for a more accurate assessment of the systematic harm done to a group and can potentially generate more effective remedies to address group injuries, thus ensuring symmetry between substantive rights and available remedies. ${ }^{239}$ Class actions are especially useful in discrimination cases, thus for the CEDAW and the CERD, but also for indigenous or other minority groups, that allege e.g. that state practices are destroying the groups' unique cultural characteristics and ability to maintain their traditional relationships with the land. ${ }^{240}$ Furthermore, injuries of a large scale with a systematic pattern as well as injuries of rights with collective aspects may be pursued by a class in cases where individual complainants are unlikely to bring a complaint, not only because this would involve a huge collective good aspect, but also because the victims are unlikely to bring an own claim, be it because they are only affected on a small scale or because the educational, economic, political and territorial situation is not conducive for bringing a claim.

In short, "collective complaints” provide complainants with several advantages. They are an efficient mechanism for pursuing large-scale litigation in cases where individual complainants are unlikely to bring their own claims. Class actions allow such victims to seek redress in a single proceeding on their own, thereby reducing transaction costs and promoting efficiency in litigation. Class action as well as NGO complaints without named victims also provide a degree of anonymity to victims who might otherwise face repercussions from the defendant state for filing individual lawsuits.

Often it is said that there is the danger of flooding human rights bodies with complaints. This argument needs to be put into question: the caseload of human rights judicial or quasi-judicial bodies varies immensely and is generally small, with the exception of the ECtHR. Within the European system, there have been ongoing discussions about the heavy caseload. ${ }^{241}$ But one should keep in mind that the ECtHR acts as a "constitutional court" of last resort for about 800 million citizens, many of those living in countries with a doubtable human rights record. Within the UN-system and the African system heavy workload is not an issue (even though that is of course also a question of funds the institutions have at their disposal ${ }^{242}$ ). Closing the doors to the

239 See ibid., at 308. She provides a broad overview of class action cases in US law and other cases, which amounted to class actions, even if strictly speaking they were not (the post WW II tribunals).

240 Ibid., 310.

241 Report of the Evaluation Group to the Committee of Ministers on the European Court of Human Rights September 2001, available at: <https://wcm.coe.int/ViewDoc.jsp?id=226195\&Lang=fr>. Art. 8 of the Protocol No. 14 to the Convention for the Protection of Human Rights and Fundamental Freedoms amending the control system of the Convention, CETS No. 194 (opened for signature 13 May 2004), amending Art. 28 ECHR, will simplify the adjudication of repetitive violations, while preserving formal equality among rights, authorising three-judge committees to issue judgments on the merits in routine cases under 'well-established case-law'. The Explanatory Report on Protocol No. 14 can be found under

$<$ http://conventions.coe.int/Treaty/EN/Reports/Html/194.htm>.

242 See for an overview on the funding of international courts in relation to their caseload, see Cesare P.R. Romano, "International Courts and Tribunals: Price, Financing and Output”, in: Stefan Voigt et al. (eds.), International Conflict Resolution. Conferences on New Political Economy 23, 2005, Tübingen, forthcoming. 
justice system on the grounds of economic expenses is not a convincing argument, especially in view of the small total amount of money which international human rights courts cost. ${ }^{243}$

Furthermore, introducing "collective complaints" could reduce the caseload of international judicial bodies. Initially there might be more cases. However, it must be kept in mind that the individual complaint is not an adequate procedural way for large-scale individual violations or for collective or minority rights. Not only because there are no de facto incentives to bring a complaint, but also because such violations lend themselves to being treated in one case. Altruistic NGO complaints as well as class action litigation could reduce such caseloads by bringing multiple victims together in a single proceeding. ${ }^{244}$ The same holds for actio popularis if e.g. the incompatibility of a law or a practice with the respective treaty is alleged (objective control).

“Collective complaints” may also further compliance with international human rights obligations and the judgments or views of the respective bodies, ${ }^{245}$ as they raise awareness and foster publicity and therefore are apt to induce compliance, which would lead to a regression of (systematic) violations. Execution of judgments or views is meant to be an integral part of the international human rights system and to contribute to ameliorating the human rights situation. Rapid and adequate execution has, of course, an effect on the influx of new cases: the more rapidly general measures are taken by States Parties to execute judgments which point to a structural problem, the fewer repetitive applications will there be. ${ }^{246}$

Using courts as a political weapon is a further argument for not admitting "collective complaints”. This argument is implausible for several reasons. First, in human rights cases, as in constitutional cases, political aspects often play a role. Judgments or views, if complied with, might have political consequences. That is no reason to deny justice in the first place as human rights have i.a. the function to protect against pragmatic policy choices. By ratifying a human rights treaty as well as its provisions for individual complaints mechanisms and not declaring reservations, a state consents to the priority of human rights issues over considerations of political expediency. In any case, purely political complaints can always be dismissed. ${ }^{247}$ Second, even if a certain human rights violation and consequently a decision of a judicial body may have political consequences those might also arise with purely individual complaints as the ECtHR Turkish Cypriot cases show. ${ }^{248}$ Therefore, that is no argument against collective complaints. Third, substantive law questions are to be separated from questions of ius standi, which is a procedural

243 The Inter-American Human rights system (Court and IACHR) only takes approximately 5.5\% of the total budget of the OAS while the ECtHR takes $21.7 \%$ of the Councils' budget see Romano, supra note 242.

244 Aceves, supra note 47, at 399 et seq.

245 Even though the implementation of the ECtHR decisions is probably better than in other regions of the world, it still poses a problem, see Opinion No. 209/2002 on the Implementation of the Judgments of the ECtHR, adopted by the Venice Commission, supra note 20.

246 See for the same argument Explanatory Report on Protocol No. 14, supra note 241, at para. 16.

247 See e.g. Art. 35 (3) ECHR.

248 This was e.g. debated in the Case of Loizidou v. Turkey (Appl. No. 15318/89), 1996-VI, No. 26 at 2216 Eur.Ct.H.R Grand Chamber Judgment of 18 December 1996, which dealt with i.a. the right to property under Art. 1 of the First Protocol in the setting of Cyprus. See e.g. Dissenting Opinion of Judge Bernhardt at para. 1 and Dissenting Opinion of Judge Jambrek at para. 7. 
question. Judicial considerations of restraint for political reasons should be found in the substantive part of a judgment, not in the admissibility of a case.

\section{Conclusion}

Empirical research shows that IHRL is largely ineffective, but individual complaint procedures are seen as one instrument that is at least minimally effective. In order to foster effectiveness, it therefore seems appropriate to strengthen the system of individual complaints by giving the victims their own enforcement tools. If enforcement by private actors is an adequate tool, we need to ask how we can render those instruments more effective. In order to answer that question, a social science analysis which is able to uncover the underlying incentive structure for potential complainants is needed. This article used the rational-choice approach. If we take a closer look at how individual complaint mechanisms function, it is discernible that the legal situation is such as to deter complaints from a rational-choice perspective. IHRL privileges individual subjective rights through its procedural provisions. It discriminates against interests which may affect a whole group or minority or the general public (e.g. environmental concerns). We have shown that the individual incentive to bring altruistic complaints on behalf of groups and for large-scale violations is small. Even if collective interests simultaneously affect an individual right, it is often the case that a lot of people are affected, but only to a minor extent, which may lead to a de facto under-enforcement as an individual action is not deemed attractive from a rational individual's point of view. This is especially true in cases where the benefit of the complaint would serve a whole collectivity, like e.g. in environmental or minority rights cases. The current legal situation hinders the effective enforcement of the human rights treaties, if one takes into account the incentive structure for potential complainants. ${ }^{249}$ "Collective complaints" change the underlying incentives for bringing complaints. They are, especially in developing countries, often the only means for bringing human rights violations before international bodies.

To sum up: If we take international human rights treaties seriously, we need to think about effective procedural provisions, which are commensurate to the occurring human rights violations. Fostering the private enforcement of IHRL seems an appropriate means. 